The Canadian Mineralogist

Vol. 41, pp. 597-616 (2003)

\title{
PLATINUM-GROUP MINERALS IN PODIFORM CHROMITITES OF THE OMAN OPHIOLITE
}

\author{
Ahmed Hassan AHMED ${ }^{\S}$ AND ShoJI ARAI \\ Department of Earth Sciences, Kanazawa University, Kakuma 920-1192, Japan
}

\begin{abstract}
Chromitite lenses rich in the platinum-group elements (PGE) have recently been discovered in the deeper part of the mantle section of the northern part of the Oman ophiolite. In terms of stratigraphic level, there are two types of chromitite: Moho transition zone (MTZ) and mantle types. The mantle type can be further classified into two subtypes: PGE-poor and PGE-rich. Platinum-group minerals (PGM) have been mainly observed in the PGE-rich mantle chromitite and, to a lesser extent, in the PGEpoor mantle chromitite, although a few PGM grains have been detected from the MTZ chromitites. The PGM comprise four main categories in the following order of abundance: (1) sulfides [Os-rich laurite, erlichmanite and unnamed (Ir, $\mathrm{Rh})(\mathrm{Ni}, \mathrm{Cu}, \mathrm{Fe})_{2} \mathrm{~S}_{3}$ ], $(2)$ sulfarsenide and arsenide (irarsite-hollingworthite series, palladoarsenide), (3) alloys and native metals [Os-Ir alloy, (Cu-Pt-FeIr-Rh) alloy, Pt-Fe alloy, (Ni-Ru-Os-Ir) alloy, Ir-Pt alloy, Ir-Rh alloy and native Pd metal], and (4) PGE oxide (Ru-Os-Ir oxide). Base-metal sulfides (BMS) and base-metal alloys (BMA) also are found, as inclusions in chromian spinel and interstitial matrix, mainly in the MTZ and PGE-poor mantle chromitites. The common abundance of PGE sulfides, i.e., Os-rich laurite, in the Oman chromitites is ascribed to the sulfide-undersaturated nature of the magma involved in chromitite formation. However, the sulfur fugacity was sufficiently high to produce the Os-rich laurite and, to a lesser extent, erlichmanite and Ru-poor Os-Ir alloy. The sulfur fugacity was higher in the formation of the PGE-poor mantle chromitite relative to the PGE-rich chromitite, as indicated by the presence of the unnamed Ir-rich sulfides and, to a lesser extent, BMS. The presence of PGE oxide commonly associated with fractured chromian spinel indicates that the PGE distribution in rocks can easily be modified at an early stage of serpentinization.
\end{abstract}

Keywords: laurite, chromitite, ophiolite, platinum-group elements, platinum-group minerals, sulfur fugacity, northern Oman.

\section{SOMMAIRE}

Nous avons récemment découvert des lentilles de chromitite enrichies en éléments du groupe du platine (EGP) dans la partie la plus profonde de la séquence mantellique de la partie nord de l'ophiolite d'Oman. Du point de vue niveau stratigraphique, nous distinguons deux sortes de chromitites, celles qui sont associées à la zone de transition du Moho (MTZ), et celles provenant du manteau sousjacent. Ces dernières comprennent à leur tour deux types, l'un pauvre en EGP et l'autre enrichi en EGP. Les minéraux du groupe du platine se trouvent surtout dans les chromitites mantelliques enrichies en EGP, quoique qu'on en trouve aussi, mais à un degré moindre, dans les chromitites mantelliques à faible teneur en EGP et dans les chromitites de type MTZ. Nous documentons quatre groupes de ces minéraux, présentés ici dans un ordre selon leur abondance: (1) sulfures [laurite osmifère, erlichmanite et $(\mathrm{Ir}, \mathrm{Rh})(\mathrm{Ni}, \mathrm{Cu}, \mathrm{Fe})_{2} \mathrm{~S}_{3}$ sans nom], (2) sulfarséniure et arséniure (série irarsite-hollingworthite, palladoarsenide), (3) alliages et métaux natifs [alliage Os-Ir, alliage ( $\mathrm{Cu}-\mathrm{Pt}-\mathrm{Fe}-\mathrm{Ir}-\mathrm{Rh}$ ), alliage $\mathrm{Pt}-\mathrm{Fe}$, alliage (Ni-Ru-Os-Ir), alliage Ir-Pt, alliage Ir-Rh et Pd natif], et (4) oxyde des EGP (oxyde Ru-Os-Ir). Nous avons aussi trouvé des sulfures et des alliages de métaux de base, en inclusion dans le spinelle chromifère et dans les interstices de la matrice, surtout dans les chromitites de type MTZ et les chromitites mantelliques à faible teneur en EGP. La présence courante de sulfures des EGP, par exemple la laurite osmifère, dans les chromitites de l'ophiolite d'Oman, serait due à la nature sous-saturée en sulfures du magma impliqué. Toutefois, la fugacité en soufre était suffisante pour que soit produit la laurite osmifère et, à un degré moindre, l'erlichmanite et un alliage Os-Ir à faible teneur en Ru. La fugacité en soufre était plus élevée lors de la formation des chromitites mantelliques à faible teneur en EGP, comme en témoigne la présence du sulfure riche en Ir sans nom et, à un degré moindre, les sulfures des métaux de base. La présence d'un oxyde des EGP en association avec le spinelle chromifère fissuré montre à quel point la distribution des EGP peut être modifiée dans ces roches à un stade précoce de leur serpentinisation.

(Traduit par la Rédaction)

Mots-clés: laurite, chromitite, ophiolite, éléments du groupe du platine, minéraux du groupe du platine, fugacité en soufre, secteur nord de l'Oman.

§ E-mail address: ahmed@earth.s.kanazawa-u.ac.jp 


\section{INTRODUCTION}

In addition to their economic importance, the platinum-group elements (PGE) are potentially useful indicators of degree of partial melting in the mantle and of sulfur saturation of a melt. That property is due to the siderophile and chalcophile nature of these precious metals, which tend to be strongly fractionated into a sulfide phase (e.g., Arculus \& Delano 1981). Although the Oman ophiolite is the largest and best preserved ophiolitic succession on Earth, the PGE it contains and the distribution of platinum-group minerals (PGM) have been poorly studied. In this paper, we provide the first comprehensive description of PGM and their paragenesis in podiform chromitite from the Oman ophiolite. The distribution and paragenesis of the PGM in chromitites will provide constraints on the behavior of PGE within the ophiolitic upper mantle. This article is complementary to that of Ahmed \& Arai (2002), which deals with PGE geochemical characteristics of the chromitites from the Oman ophiolite, and the tectonic significance of the PGE distribution.

\section{BACKGROUND INFORMATION}

It is noteworthy that almost all the previous PGE and PGM studies of the Oman chromitites (Brown 1982, Page et al. 1982b, Augé 1986, Leblanc \& Ceuleneer 1992, Prichard et al. 1996a) have dealt mainly with the shallower pods located at the Moho transition zone (MTZ) or even slightly deeper (2-3 km below the Moho), where PGE-poor chromitites are certainly found. A review of the PGE and PGM studies in the Oman chromitites was summarized in Ahmed \& Arai (2002). These studies have led to the following conclusions: (1) PGE contents and ratios are not correlated with chemical properties of silicates and chromite; (2) the chromitite-forming processes in the Oman ophiolite may be different from those pertinent to stratiform intrusions in terms of concentrations and distributions of PGE; (3) chromitites seem to contain PGM in Oman less commonly than in other ophiolites; (4) the only PGM found so far in chromitites at Oman is laurite, and (5) the magma from which the chromitites were formed was possibly derived from a MORB-type basalt, or from mantle materials previously depleted in PGE. Recently, Ahmed \& Arai (2002) have reported unusually highPGE chromitite in the deeper part of the mantle section exposed in the northern Oman Mountains. The high concentrations of PGE are reported only in the discordant pods of chromitite deeper within the mantle section that displays high- $\mathrm{Cr} \#$ spinel $[\mathrm{Cr} \#=\mathrm{Cr} /(\mathrm{Cr}+\mathrm{Al})$ atomic ratio, $>0.7]$.

The PGM are mainly found in the discordant PGErich chromitite pods and, to a lesser extent, in the lenses of concordant PGE-poor chromitite that occur near the PGE-rich chromitite. In addition, a few PGM grains are also described from the MTZ chromitite at Wadi Rajmi
(Fig. 1A). The PGM are mostly found as inclusions within completely fresh grains of chromian spinel, and subordinately in the cracks in chromian spinel and in the silicate matrix. Base-metal sulfides (BMS) and basemetal alloys (BMA) are also included in or interstitial to chromian spinel.

\section{Geological Setting and Sample Locations}

Owing to the simple structure and stratigraphy exposed in the northern Oman Mountains, a complete sequence of ophiolite is well preserved and exposed from the upper mantle to the upper crust (Fig. 1A). There are several wadis (i.e., valleys) cutting the ophiolite from west to east downstream, which provide excellent exposures of rocks with which to examine the whole section. The northern Oman mantle section consists mainly of pervasively foliated harzburgite with minor amounts of dunite, chromitite and basal lherzolite (Lippard et al. 1986). Dunite is predominant over harzburgite in the uppermost part of the mantle, forming the MTZ. Concordant layers of orthopyroxenite up to $6 \mathrm{~m}$ thick, associated with dunite, are found in harzburgite in the lower part of the mantle section.

As in many other ophiolite complexes, chromitite deposits are occasionally found at the uppermost part of the mantle section, just at the Moho transition zone in the Oman ophiolite (Nicolas \& Al Azri 1991). Large pods of chromitite have also been found recently deeper within the mantle section of the Oman ophiolite. Among four chromitite localites examined in the northern Oman ophiolite (Fig. 1A), PGM have been found only in two localities, Wadi Hilti and Wadi Rajmi. In spite of a systematic investigation, no PGM have been found in chromitites exposed along Wadi Farfar and Wadi Fizh. The absence of PGM is confirmed by the very low PGE concentrations in chromitites from these two localities (Ahmed \& Arai 2002). Chromitites located deeper within the mantle ( $>5 \mathrm{~km}$ below the Moho) are found only at Wadi Hilti, whereas at the other localities, Wadi Rajmi, Wadi Farfar and Wadi Fizh, they are located just at the boundary between the mantle and crust or at a few kilometers (1-2 km) below the Moho (Fig. 1A). At a deeper horizon within the mantle section at Wadi Hilti (Fig. 1B), two types of chromitite have been distinguished in terms of mode of occurrence: concordant (lensoid shape) and discordant (dike-like) chromitites (Ahmed \& Arai 2002). The former is slightly deeper within the mantle than the latter, and they are about 500 $\mathrm{m}$ apart horizontally from one another.

FIG. 1. Geological sketch-maps of the study area (A) and the PGE-mineralized chromitite locality (B) at Wadi Hilti in the deeper mantle section, Oman ophiolite. 


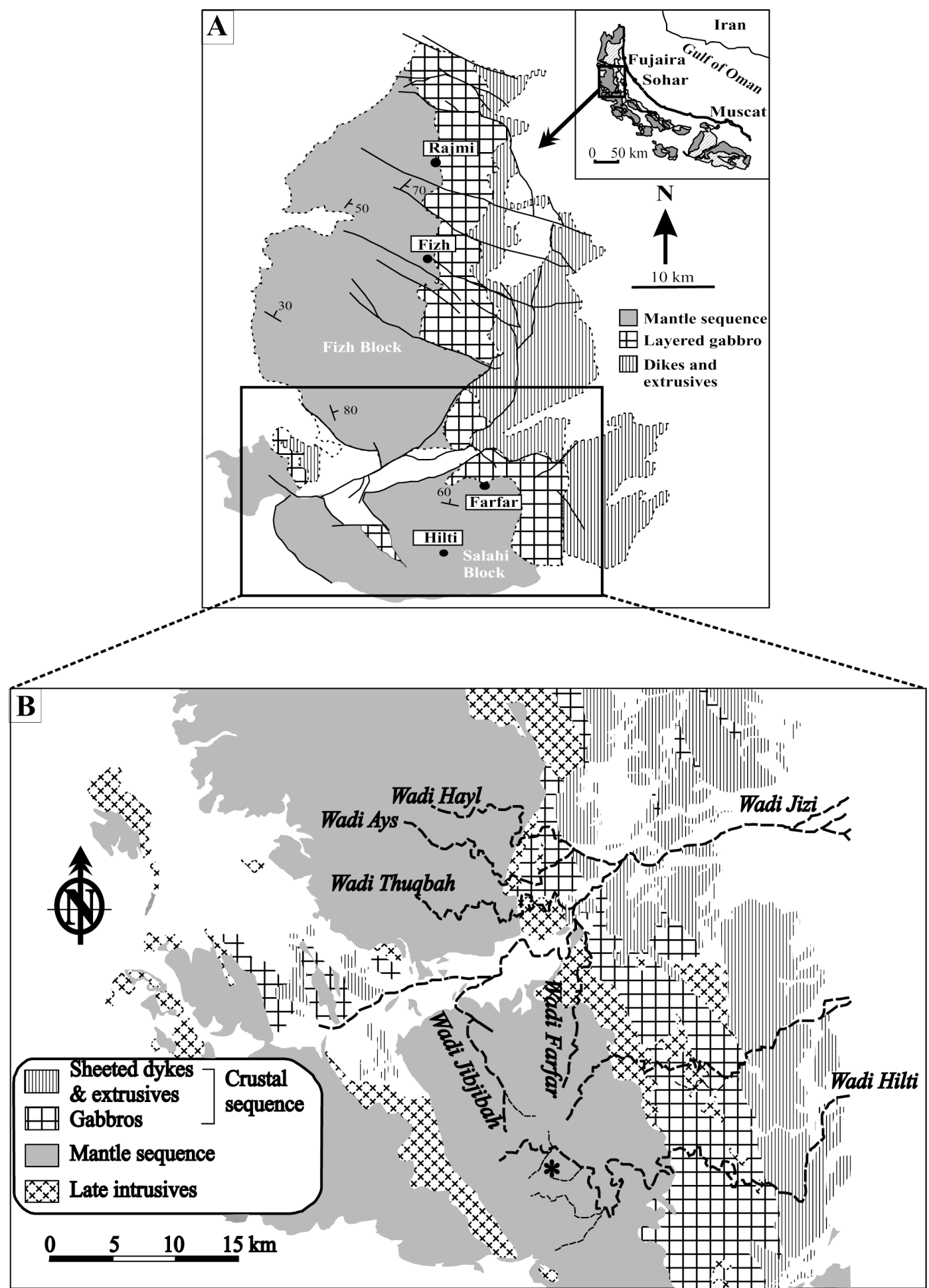

* Location of PGE-mineralized chromitite (Wadi Hilti) 


\section{Petrographic Descriptions AND GeOChemical Notes}

The massive MTZ chromitites are occasionally cross-cut by feldspathic and gabbroic veins, and their interstitial silicate matrix consists exclusively of clinopyroxene and amphibole. The deeper chromitite at Wadi Hilti has olivine as interstitial silicate and is free of clinopyroxene and amphibole (Ahmed \& Arai 2002). The two types of chromitite in the deeper part of the mantle section also differ in mineral inclusions in chromian spinel: mainly olivine for the concordant pod of chromitite, and mostly clinopyroxene and hydrous silicates such as amphibole and phlogopite for the discordant variety (Ahmed \& Arai 2002). A high concentration of PGE is observed only in the discordant chromitite deeper within the mantle section, which has spinel with Cr\# in excess of 0.7. All the other types of chromitite that are associated with the MTZ and the concordant lenses in the deeper mantle section are poor in PGE and tend to have lower-Cr\# spinel (maximum $0.6)$. In general, the PGE content of chromitites tends to increase with an increase in the proportion and $\mathrm{Cr} \#$ of the spinel (Crocket 1979, Page et al. 1982b, Economou 1986, Leblanc 1991). The Al-rich $(\mathrm{Cr} \# \approx 0.5) \mathrm{MTZ}$ chromitites of the northern Oman section display low levels of the PGE compared to the chromitites containing spinel with intermediate- $\mathrm{Cr}(\mathrm{Cr} \#$ around 0.6) and Cr-rich (Cr\# > 0.7) values in the deeper mantle section, such that there is a strong positive correlation between $\mathrm{Cr} \#$ of spinel and PGE contents (Fig. 2). The high level of the PGE with increasing $\mathrm{Cr}$ content suggests the coprecipitation of chromian spinel and PGM at a deeper level in the upper mantle (e.g., Arai et al. 1999).

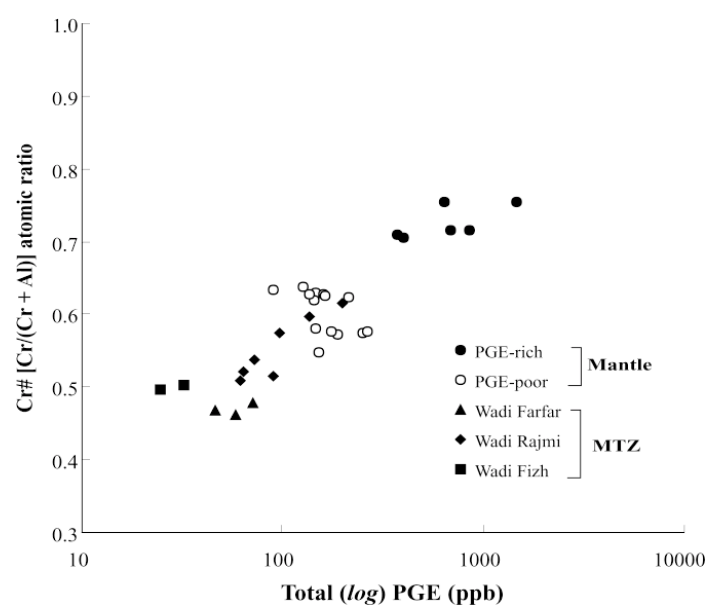

FIG. 2. Variation of Cr\# versus the total (log) PGE contents in the chromitites studied from the Oman ophiolite. Cr\# is defined as $\mathrm{Cr} /(\mathrm{Cr}+\mathrm{Al})$, atomic ratio.
Analytical Techniques

Polished thin sections of analyzed samples have been examined at high magnifications so that we could detect very small grains of PGM down to $1 \mu \mathrm{m}$ across. Chemical analyses were carried out using a JEOL JXA8800 electron-probe micro-analyzer at the Center for Co-operative Research at Kanazawa University, Japan. Analytical conditions were $25 \mathrm{kV}$ accelerating voltage and $20 \mathrm{nA}$ probe current for all elements except oxygen. Analysis of the minerals for oxygen was conducted at $10 \mathrm{kV}$ and $50 \mathrm{nA}$ in a separate run using LDE analyzing crystals; the grains were analyzed both qualitatively and semiquantitatively using wavelength-dispersion spectroscopy (WDS). Counting time was 10 seconds for all elements. Pure metals were used as standards for the elements $\mathrm{Os}, \mathrm{Ir}, \mathrm{Ru}, \mathrm{Rh}, \mathrm{Pt}, \mathrm{Pd}, \mathrm{Cu}, \mathrm{Ni}, \mathrm{Fe}$ and $\mathrm{Cr}$, whereas gallium arsenide was used for As, and pentlandite for $\mathrm{S}$. Two oxides, $\mathrm{Fe}_{2} \mathrm{O}_{3}$ and $\mathrm{Al}_{2} \mathrm{O}_{3}$, were used as standards for oxygen. We used the $K \alpha \mathrm{X}$-ray lines for $\mathrm{Ni}, \mathrm{S}, \mathrm{Fe}, \mathrm{Cr}$ and $\mathrm{O}$, the $L \alpha$ lines for $\mathrm{Os}, \mathrm{Ir}, \mathrm{Ru}, \mathrm{Rh}, \mathrm{Pt}$ and $\mathrm{Cu}$, and the $L \beta$ lines for $\mathrm{Pd}$ and As.

\section{The Platinum-Group Minerals and Textural Relationships}

More than 200 polished thin sections of chromitite and related rocks have been examined for the occurrence of PGM. Only samples from the mantle PGE-rich and PGE-poor chromitites at Wadi Hilti and, to a lesser extent, MTZ chromitite from Wadi Rajmi were found to contain PGM. The most common PGM is laurite, ideally $\mathrm{RuS}_{2}$ as a Ru-rich phase, whereas the least abundant is native Pd as Pd metal (Fig. 3). Four groups of PGM have been found in the northern Oman chromitites: sulfides, sulfarsenides, alloys and oxide.

\section{Platinum-group sulfides}

Platinum-group sulfides in the northern Oman chromitites are mostly found to be enclosed within fresh chromian spinel and, in a few cases, within the interstitial matrix and fractures in spinel, but they do not display any chemical variations depending on their mode of occurrence. The grain size of the PGM sulfides occasionally attains $30 \mu \mathrm{m}$. In most cases, it is Os-rich laurite that is found, as solitary grains of euhedral shape embedded within fresh chromian spinel (Figs. 4A, B, C). This occurrence is contrary to that observed by Augé (1986), where laurite is occasionally associated with silicates. In a few cases, the laurite is associated with inclusions of primary anhydrous silicates like orthopyroxene and clinopyroxene (Fig. 4D), or with primary hydrous silicates like amphibole and phlogopite (Fig. $4 \mathrm{E})$. Os-rich laurite of similar morphology and composition also is found both in the olivine matrix (Fig. 4F) and within fractures of chromian spinel (Fig. 4G). A few grains of erlichmanite also are found as euhedral to 
subhedral crystals up to $5 \mu \mathrm{m}$ across within fresh chromian spinel (Fig. 4H); in some cases, it is associated with possible fluid inclusions (Fig. 4I).

An unnamed $(\mathrm{Ir}, \mathrm{Rh})(\mathrm{Ni}, \mathrm{Cu}, \mathrm{Fe})$ sulfide is found only in the mantle PGE-poor chromitite. Its occurrence is coincident with the positive Ir anomaly observed in the PGE distribution patterns of the mantle PGE-poor chromitite (Ahmed \& Arai 2002). This mineral generally shows a lower reflectance than the associated laurite, and exhibits a grey to bluish grey color in reflected light. In most cases, this unnamed sulfide occurs either as monomineralic inclusions or as composite inclusions with Os-rich laurite (Fig. 4J) or silicates (Fig. $4 \mathrm{~K})$. It shows a subhedral to anhedral shape in grains up to $10 \mu \mathrm{m}$ across.

\section{Platinum-group sulfarsenides}

Platinum-group sulfarsenides are represented mainly by a solid-solution series between irarsite and hollingworthite end-members, with a variable Rh content. They are found as single crystals of euhedral to subhedral shape enclosed in intact (Fig. 5A) or fractured (Figs. 5B, C) chromian spinel. The sulfarsenides have the same morphology and composition in either textural types of spinel.

\section{Platinum-group alloys}

An osmium-iridium alloy is the most common of the PGE alloys in the northern Oman chromitites; the grains show a subhedral to round shape of less than 5 $\mu \mathrm{m}$ across (Figs. 5D, E). Like the grains of sulfides, the grains of Os-Ir alloy are occasionally included within fresh chromian spinel but are absent in the silicate matrix or spinel cracks. It is noteworthy that there are usually voids around the inclusions of Os-Ir alloy (Figs. $5 \mathrm{D}, \mathrm{E})$. The grains of $\mathrm{Cu}-\mathrm{Pt}-\mathrm{Fe}-\mathrm{Ir}-\mathrm{Rh}$ alloy are also found as discrete inclusions, locally associated with irarsite in chromian spinel of the PGE-poor chromitite, and display a subhedral to round shape, up to $5 \mu \mathrm{m}$ across (Fig. 5F). Grains of an unidentified Ni-Ru-OsIr alloy have been observed as inclusions within chromian spinel of the PGE-poor chromitite. They show a euhedral shape of about $5 \mu \mathrm{m}$ across (Fig. 5G). Grains of Ir-Pt and Ir-Rh alloy are found to be associated with Os-rich laurite within chromian spinel. They occur as small blebs, less than $5 \mu \mathrm{m}$ across (Figs. 5H, I). One composite grain of PGE alloy observed within a crack in chromian spinel of the PGE-poor chromitite displays an anhedral shape, and is about $30 \mu \mathrm{m}$ across (Fig. 5J). It consists of aggregates of $\mathrm{Ir}-\mathrm{Pt}$ and $\mathrm{Pt}-\mathrm{Fe}$ alloys, as well as $\mathrm{Pd}$ metal and $\mathrm{Pd}$ arsenide, all of which are intergrown around an irarsite grain (Fig. 5J).

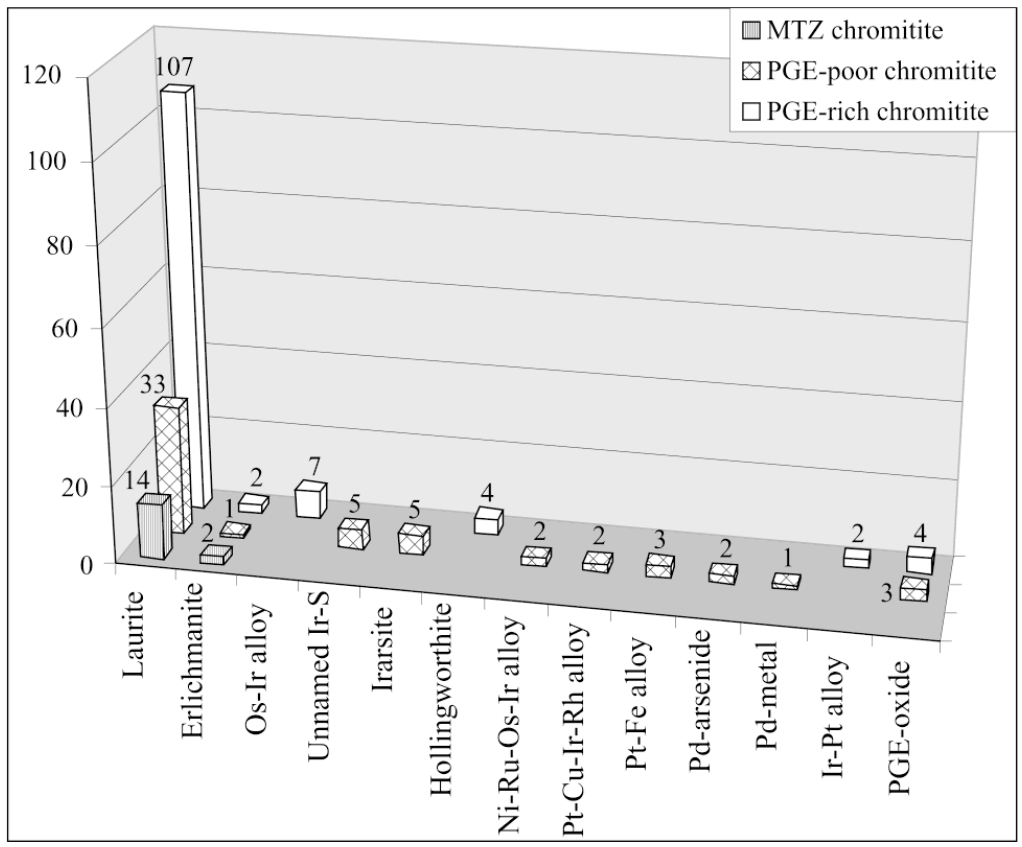

FIG. 3. Frequency histograms of the PGM species in different types of chromitite in the Oman ophiolite. Note the distinctive abundance of laurite among the PGM. 

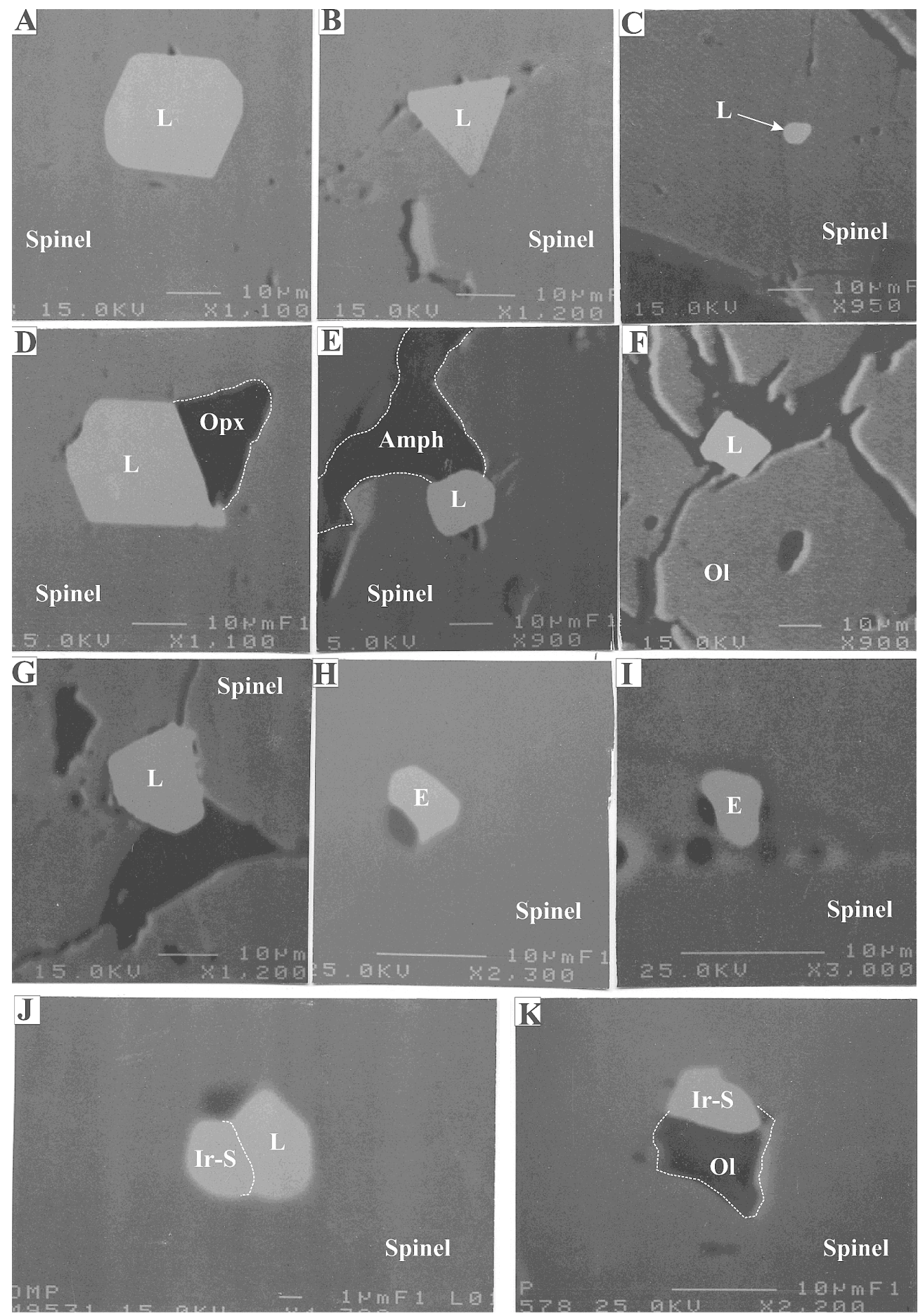

FIG. 4. Back-scattered electron images of PGE sulfides (A-K) in the northern Oman chromitites. A, B, D, E, G and H are from PGE-rich chromitite. C is from MTZ chromitite, and F, I, J and K are from PGE-poor chromitite. Abbreviations: L, Os-rich laurite; E, erlichmanite; Ir-S, unnamed $(\mathrm{Ir}, \mathrm{Rh})(\mathrm{Ni}, \mathrm{Cu}, \mathrm{Fe})$ sulfide; Opx, orthopyroxene; Ol, olivine; Spinel, host chromian spinel. 

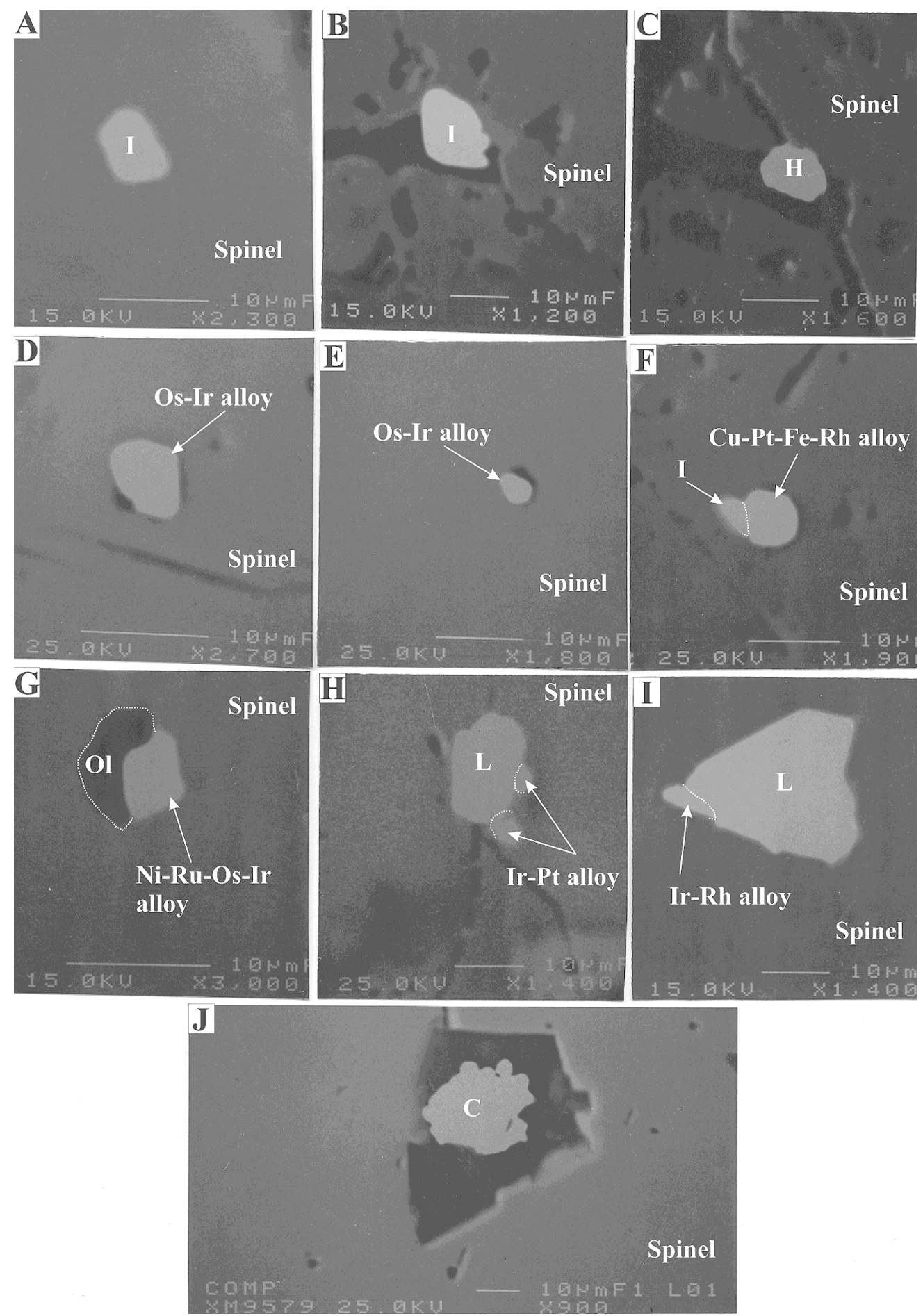

FIG. 5. Back-scattered electron images of PGE sulfarsenides (A-C), and PGE alloys (D-J) from the northern Oman chromitites. A, G and $\mathrm{J}$ are from the mantle PGE-poor chromitite, and B, C, D, E, F, H and I are from the PGE-rich chromitite. Abbreviations: I, irarsite; H, hollingworthite; L, Os-rich laurite; C, composite PGM grain. 

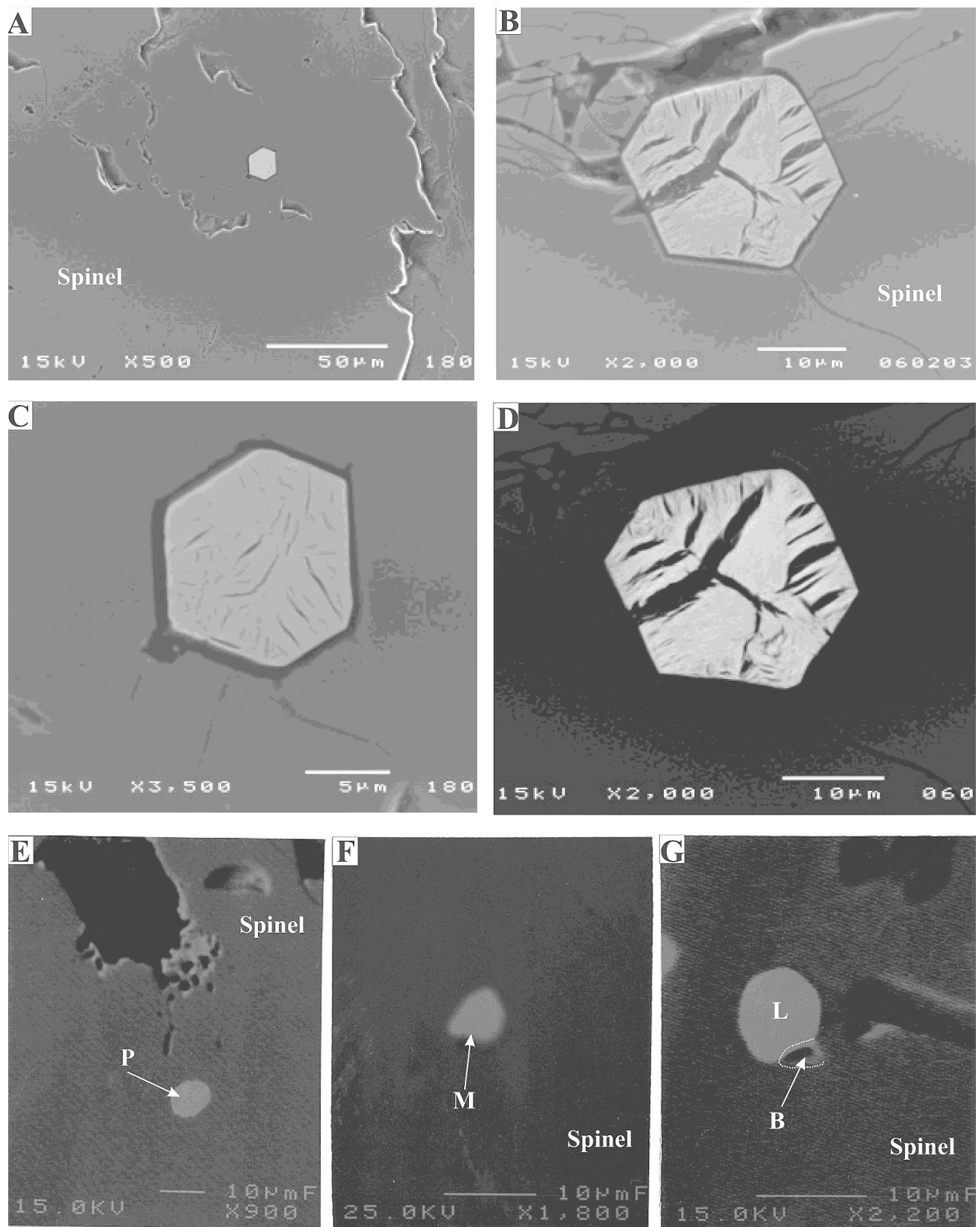

FIG. 6. Back-scattered electron images (A-D) of the PGE oxide grains, and (E-G) of BMS grains from the northern Oman chromitites. Image $\mathrm{C}$ is a close-up of $\mathrm{A}$. Abbreviations: $\mathrm{P}$, pentlandite; $\mathrm{M}$, millerite; $\mathrm{B}$, bornite. 


\section{Platinum-group oxide}

A few grains of PGM with a relatively low reflectance and unusual textures are found as inclusions within apparently unaltered chromian spinel. These grains have attracted our attention also owing the low analytical totals. They were interpreted as PGE oxide (Ahmed et al. 2002). They show a yellowish white color and range from 15 up to $50 \mu \mathrm{m}$ in size, with perfect polygonal shapes (Figs. 6A, B) within chromian spinel grains, which are usually fractured but chemically intact. In most cases, the grains show characteristic radial cracks, which are usually continuous with the cracks in the host spinel (Fig. 6C). Such grains usually have void space around them (Figs. 6C, D). It is noteworthy that the polygonal PGM (oxide) have cracks, in some cases radiating, of various dimensions (Figs. 6A, C). The radial cracks of PGE oxide and those in the chromian spinel are occasionally filled by serpentine-group minerals, whereas chlorite is usually absent (Ahmed et al. 2002). These features indicate a significant decrease in volume on formation of the PGE oxide. Similar cracking was reported in PGE oxides in chromitites and related alluvium of the New Caledonian ophiolite (Augé \& Legendre 1994) and the Nurali ultramafic complex, southern Urals (Garuti et al. 1997). The void space around PGE oxides was recognized in chromitite from the Vourinos ophiolite (Garuti \& Zaccarini 1997). Laurite and other PGM are free of radial cracking and usually show a homogeneous appearance (see Figs. 4, 5).

\section{Base-metal sulfides (BMS) and alloys (BMA)}

Grains of base-metal sulfides and alloys are occasionally found as small inclusions within chromian spinel or as larger aggregates in the silicate matrix and altered parts of chromian spinel. They are much more abundant in the PGE-poor and MTZ chromitites than in the PGE-rich chromitite. They consist of the following minerals, in decreasing order of abundance: $\mathrm{Ni}-\mathrm{Fe}$ alloy, pentlandite, unknown $\mathrm{Cu}$-rich $\mathrm{Ni}-\mathrm{Fe}$ sulfide, millerite, bornite and heazlewoodite. Inclusions of pentlandite and unknown $\mathrm{Cu}$-rich $\mathrm{Ni}-\mathrm{Fe}$ sulfide occasionally show a droplet shape (Figs. 6E, H), up to 10 $\mu \mathrm{m}$ across, within unaltered chromian spinel of the PGE-poor and MTZ chromitites. Bornite is usually found as minute grains associated with Os-rich laurite enclosed by chromian spinel (Fig. 6G). The grains of $\mathrm{Ni}-\mathrm{Fe}$ alloy and millerite are usually found as large aggregates in the interstitial silicate matrix and within altered parts of the chromian spinel.

\section{Composition of the Minerals}

\section{Laurite-erlichmanite series}

There is a distinct compositional gap between erlichmanite and laurite in the northern Oman chromi- tites (Fig. 7A), as has been found elsewhere. Laurite is accounts for about $75 \%$ of all the PGM grains found. In almost all cases, the laurite is the Os-rich variety (Augé 1985), in which $\mathrm{Ru} /(\mathrm{Ru}+\mathrm{Os}+\mathrm{Ir})$ varies from 0.54 up to 0.76 (atomic ratio). In most cases, laurite from different types of chromitite has a similar compositional range, with $\mathrm{Ru}>\mathrm{Os}>\mathrm{Ir}$ in atomic proportions (Fig. 7A, Tables 1,2). The Os content varies from 12 up to 34 $\mathrm{wt} \%$, and is $18.8 \mathrm{wt} \%$ on average, indicating a remarkable extent of substitution of Os for $\mathrm{Ru}$. The Ir content does not substantially vary, ranging from 6 up to 13.8 wt $\%$, about 9 wt $\%$ on average. The average composition $(n=154)$ is $\left(\mathrm{Ru}_{0.66} \mathrm{Os}_{0.23} \mathrm{Ir}_{0.11}\right) \mathrm{S}_{2}$, and the richest one in Os is $\left(\mathrm{Ru}_{0.49} \mathrm{Os}_{0.41} \mathrm{Ir}_{0.10}\right) \mathrm{S}_{2}$ (Table 2, Fig. 7A). The grains are rather homogeneous. $\mathrm{Rh}, \mathrm{Ni}$ and $\mathrm{Fe}$ were detected as minor elements, with average concentrations of $0.9,0.2$ and $0.6 \mathrm{wt} \%$, respectively (Table 1 ).

Erlichmanite, ideally $\mathrm{OsS}_{2}$, also is characterized by extensive substitution of $\mathrm{Ru}$ for Os, and its average composition is $\left(\mathrm{Os}_{0.58} \mathrm{Ru}_{0.25} \mathrm{Ir}_{0.17}\right) \mathrm{S}_{2}$. Erlichmanite in some cases shows a very high Ir content, ranging from 7 up to 20.8 wt\% (Table 2). Minor amounts of Rh, Ni and Fe have been detected, with average concentrations of 0.4 , 0.04 and $1.3 \mathrm{wt} \%$, respectively. The relatively high $\mathrm{Cr}$ content in some cases of laurite-erlichmanite minerals is due to a fluorescence effect from the chromian spinel host; those compositions were, therefore, corrected by subtraction of the $\mathrm{Cr}$ content.

\section{Unnamed $(\mathrm{Ir}, \mathrm{Rh})(\mathrm{Ni}, \mathrm{Cu}, \mathrm{Fe})_{2} \mathrm{~S}_{3}$}

This mineral has been found only in the PGE-poor chromitite as discrete inclusions within chromian spinel. The ratio $(\mathrm{Ni}+\mathrm{Cu}+\mathrm{Fe}) /(\mathrm{Ir}+\mathrm{Rh})$ varies from 1.15 to 2.54 (2.0 on average). The mineral usually contains minor amounts of $\mathrm{Os}, \mathrm{Ru}$ and $\mathrm{Pt}$, with average concentrations of $0.2,0.9$ and $2.0 \mathrm{wt} \%$, respectively. The average chemical formula of this mineral is $\left(\mathrm{Ir}_{0.76} \mathrm{Rh}_{0.24}\right)$ $\left(\mathrm{Ni}_{0.36} \mathrm{Cu}_{0.29} \mathrm{Fe}_{0.35}\right)_{\Sigma 2} \mathrm{~S}_{3}$. This formula is comparable to what has been reported from other ultramafic complexes (Fig. 7B) such as the Tiebaghi ophiolitic complex (Augé 1988), ultramafic massifs of Finero, Italy, and Ojén, Spain (Garuti et al. 1995), and the Ray-Iz ultramafic complex, Polar Urals, Russia (Garuti et al. 1999b). The above-mentioned authors defined this mineral as a Ir$\mathrm{Cu}$ sulfide, unknown \#1, probably $(\mathrm{Ni}, \mathrm{Fe}, \mathrm{Cu})_{2}(\mathrm{Ir}, \mathrm{Rh}) \mathrm{S}_{3}$, and an unknown $\mathrm{Ir}-\mathrm{Rh}-\mathrm{Ni}$ sulfide, respectively. There is a debate whether this mineral is a new mineral species (Garuti et al. 1995, Torres-Ruiz et al. 1996) or a variety of PGE-rich pyrrhotite or pentlandite (Cabri 1981). Its mode of occurrence and paragenetic assemblage in the northern Oman chromitite support the first suggestion.

\section{Irarsite-hollingworthite series}

Irarsite (IrAsS) and hollingworthite (RhAsS) are the only PGE sulfarsenides observed in the northern Oman 
chromitites. The two end-members show a wide range of solid solution (Table 3, Fig. 8A). The irarsite richest in Ir has less than $3 \mathrm{wt} \% \mathrm{Rh}$, with an average chemical formula of $\left(\operatorname{Ir}_{0.87} \mathrm{Ru}_{0.08} \mathrm{Rh}_{0.05}\right) \mathrm{AsS}$, whereas the hollingworthite richest in $\mathrm{Rh}$ has up to $6.4 \mathrm{wt} \% \mathrm{Ir}$, with an average formula of $\left(\mathrm{Rh}_{0.89} \mathrm{Ir}_{0.07} \mathrm{Pt}_{0.04}\right) \mathrm{AsS}$. The $\mathrm{Rh}: \mathrm{Ir}$ ratio is positively and negatively correlated, respectively, with $\mathrm{Pt}$ (up to $5.5 \mathrm{wt} \%$ ) and $\mathrm{Ru}$ (up to $2.6 \mathrm{wt} \%$ ) (Fig. 8A, Table 3).

\section{Pd arsenide (palladoarsenide)}

Pd arsenide is found as part of composite PGM grains intergrown around irarsite. Its chemical formula, $\left(\mathrm{Pd}_{0.68} \mathrm{As}_{0.30} \mathrm{Cu}_{0.02}\right)$, is close to the ideal composition of palladoarsenide $\left(\mathrm{Pd}_{2} \mathrm{As}\right)$ reported from various locali- ties (Cabri 1981). It has minor amounts of $\mathrm{Cu}$ and $\mathrm{Pt}$, being up to 1.1 and $0.8 \mathrm{wt} \%$, respectively (Table 3). Hence, its formula can be written as $\left(\mathrm{Pd}_{0.98} \mathrm{Cu}_{0.02}\right)_{\Sigma 2} \mathrm{As}$, which is comparable to what has been reported from the Stillwater Complex, Montana (Cabri 1981).

\section{Alloys}

The chemical composition of the Os-Ir alloy ranges from $\left(\mathrm{Os}_{0.43} \mathrm{Ir}_{0.44} \mathrm{Ru}_{0.09} \mathrm{Fe}_{0.04}\right)$ to $\left(\mathrm{Os}_{0.79} \mathrm{Ir}_{0.16} \mathrm{Ru}_{0.02}\right.$ $\left.\mathrm{Fe}_{0.03}\right)$, with an average formula of $\left(\mathrm{Os}_{0.58} \mathrm{Ir}_{0.36} \mathrm{Ru}_{0.03}\right.$ $\mathrm{Fe}_{0.03}$ ). The alloy is comparable to the osmium-iridium series reported from various localities (Cabri 1981). Variable amounts of Ru, 0.3-4.1 wt\% (1.5 wt\% on average), $\mathrm{Fe}, 0.4-1.2 \mathrm{wt} \%$ (0.8 wt $\%$ on average), and $\mathrm{Pd}$, up to $0.5 \mathrm{wt} \%$, have been detected in the Os-Ir alloy (Table 4, Fig. 8B).

\section{A) Laurite-erlichmanite}
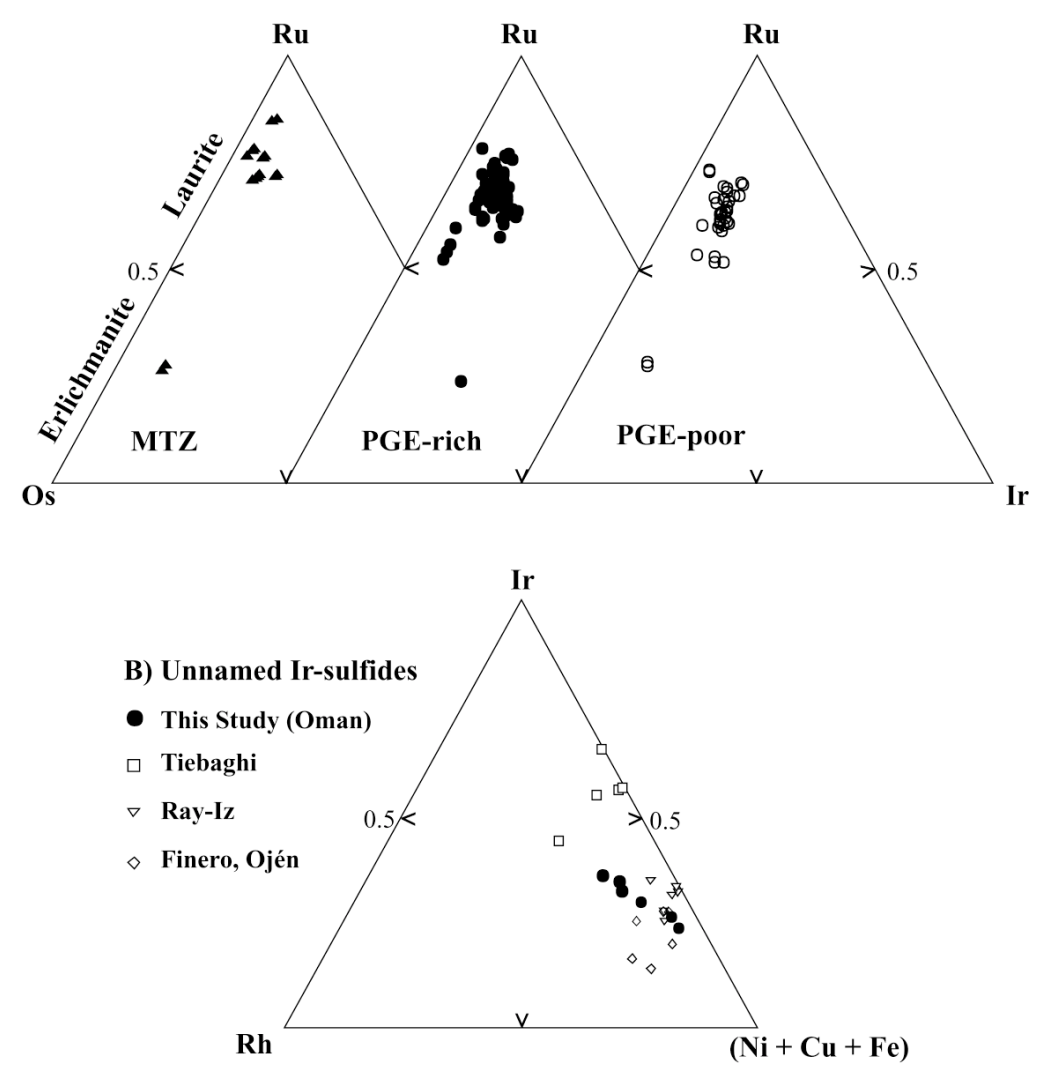

FIG. 7. Compositional variation of PGE sulfides in terms of (A) Ru-Os-Ir of the lauriteerlichmanite series, and (B) $\mathrm{Ir}-\mathrm{Rh}-(\mathrm{Ni}+\mathrm{Cu}+\mathrm{Fe})$ of the unnamed $(\mathrm{Ir}, \mathrm{Rh})(\mathrm{Ni}, \mathrm{Cu}, \mathrm{Fe})$ sulfide from the northern Oman chromitites. The unnamed $(\mathrm{Ir}, \mathrm{Rh})(\mathrm{Ni}, \mathrm{Cu}, \mathrm{Fe})$ sulfide from the Tiebaghi complex (Augé 1988), Rai-Iz complex (Garuti et al. 1999b) and Finero and Ojén (Ferrario \& Garuti 1990) are shown here for comparison. Note the overlap of the samples studied with the samples from Rai-Iz, Finero and Ojén. 
TABLE 1. REPRESENTATIVE COMPOSITIONS OF OS-RICH LAURITE IN CHROMITITE, OMAN OPHIOLITE

\begin{tabular}{|c|c|c|c|c|c|c|c|c|c|c|c|c|}
\hline \multirow{2}{*}{$\begin{array}{l}\text { Wt \% } \\
\text { S. No. }\end{array}$} & \multicolumn{4}{|c|}{ MTZ } & \multicolumn{4}{|c|}{ PGE-poor } & \multicolumn{4}{|c|}{ PGE-rich } \\
\hline & 32 & 30 & 29 & 60 & $44-2$ & $43-1$ & $43-6$ & $18-1$ & $67-3$ & $68-1$ & $68-5$ & $11-2$ \\
\hline $\mathrm{S}$ & 35.04 & 33.79 & 33.42 & 32.21 & 31.23 & 33.17 & 33.17 & 32.12 & 32.37 & 34.30 & 33.39 & 34.62 \\
\hline Os & 15.03 & 18.01 & 18.99 & 16.31 & 22.78 & 18.58 & 21.07 & 22.07 & 21.33 & 18.29 & 17.77 & 12.91 \\
\hline Ir & 10.25 & 7.37 & 6.73 & 3.37 & 9.50 & 10.14 & 3.20 & 11.83 & 6.44 & 9.52 & 12.45 & 8.16 \\
\hline $\mathrm{Ru}$ & 33.45 & 34.95 & 33.75 & 37.06 & 29.78 & 31.52 & 34.65 & 28.03 & 31.07 & 34.37 & 31.53 & 37.92 \\
\hline $\mathrm{Rh}$ & 1.14 & 1.04 & 1.12 & 0.58 & 0.69 & 0.58 & 0.69 & 0.70 & 0.73 & 1.84 & 0.80 & 1.00 \\
\hline $\mathrm{Pt}$ & - & - & - & - & - & - & - & - & 0 & - & 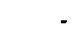 & \\
\hline Pd & - & - & 0.17 & 0.02 & - & 0.30 & 0.08 & 0.01 & 0.15 & 0.11 & 0.16 & \\
\hline As & - & - & - & - & - & - & - & - & 0 & - & & \\
\hline $\mathrm{Ni}$ & 0.35 & 0.13 & 0.12 & 0.15 & 0.04 & 0.09 & 0.08 & 0.09 & 0.38 & - & 0.07 & 0.22 \\
\hline $\mathrm{Cu}$ & - & - & & - & - & - & - & - & 0.67 & & & \\
\hline $\mathrm{Fe}$ & 0.79 & 0.65 & 0.64 & 1.46 & 0.85 & 0.68 & 1.00 & 0.52 & 1.37 & 0.11 & 0.27 & 0.73 \\
\hline $\mathrm{Cr}$ & 1.55 & 1.58 & 2.03 & 3.84 & 2.23 & 1.74 & 3.23 & 1.72 & 3.66 & 1.22 & 2.31 & 2.02 \\
\hline Total & 97.60 & 97.52 & 96.94 & 94.99 & 97.09 & 96.79 & 97.16 & 97.07 & 98.17 & 99.11 & 98.74 & 97.58 \\
\hline At $\%$ & & & & & & & & & & & & \\
\hline $\mathrm{S}$ & 68.85 & 67.70 & 67.81 & 66.57 & 66.69 & 68.11 & 67.55 & 67.94 & 66.74 & 67.86 & 68.21 & 67.83 \\
\hline Os & 4.98 & 6.09 & 6.50 & 5.69 & 8.21 & 6.44 & 7.24 & 7.88 & 7.42 & 6.11 & 6.13 & 4.27 \\
\hline Ir & 3.36 & 2.46 & 2.28 & 1.16 & 3.38 & 3.47 & 1.09 & 4.17 & 2.22 & 3.14 & 4.24 & 2.67 \\
\hline $\mathbf{R u}$ & 20.85 & 22.21 & 21.72 & 24.30 & 20.17 & 20.52 & 22.38 & 18.80 & 20.32 & 21.57 & 20.43 & 23.57 \\
\hline $\mathrm{Rh}$ & 0.70 & 0.65 & 0.71 & 0.37 & 0.46 & 0.37 & 0.44 & 0.46 & 0.47 & 1.13 & 0.51 & 0.61 \\
\hline $\mathbf{P t}$ & - & - & - & - & - & - & - & & - & & - & \\
\hline Pd & - & - & 0.10 & 0.01 & - & 0.19 & 0.05 & 0.01 & 0.10 & 0.06 & 0.10 & - \\
\hline As & - & - & - & - & - & - & - & - & 0 & - & 0 & \\
\hline $\mathrm{Ni}$ & 0.38 & 0.14 & 0.13 & 0.17 & 0.04 & 0.10 & 0.09 & 0.10 & 0.43 & - & 0.07 & 0.24 \\
\hline $\mathrm{Cu}$ & & & - & - & - & - & - & - & 0.69 & - & 0 & \\
\hline $\mathrm{Fe}$ & 0.89 & 0.75 & 0.75 & 1.73 & 1.04 & 0.80 & 1.16 & 0.63 & 1.63 & 0.13 & 0.31 & 0.82 \\
\hline
\end{tabular}

MTZ: chromitite from the Moho transition zone, Wadi Rajmi. PGE-poor: lensoid chromitite from the deeper mantle section of Wadi Hilti. PGE-rich: dike-like chromitite from the deeper mantle section of Wadi Hilti. S. No.: sample numbers. Electron-microprobe data.

TABLE 2. REPRESENTA TIVE COMPOSITIONS OF ERLICHMANI'LE AND UNNAMED $(\mathrm{Ir}, \mathrm{Rh})(\mathrm{Ni}, \mathrm{Cu}, \mathrm{Fe})_{2} \mathrm{~S}_{3}$ IN CHROMITITE, OMAN OPHIOLITE

\begin{tabular}{|c|c|c|c|c|c|c|c|c|c|c|}
\hline \multirow{2}{*}{$\begin{array}{l}\text { Wt \% } \\
\text { S. No. }\end{array}$} & \multicolumn{5}{|c|}{ Erlichmanite } & \multicolumn{5}{|c|}{$(\mathrm{Ir}, \mathrm{Rh})(\mathrm{Ni}, \mathrm{Cu}, \mathrm{Fe})_{2} \mathrm{~S}_{3}$} \\
\hline & $29-2$ & $29-3$ & $11-3$ & $67-1$ & $68-3$ & $43-1$ & $43-2$ & $43-6$ & $18-1$ & $18-2$ \\
\hline S & 26.19 & 26.69 & 14.48 & 30.69 & 30.49 & 26.37 & 25.79 & 26.88 & 25.50 & 26.68 \\
\hline Os & 41.68 & 43.97 & 41.77 & 30.04 & 34.79 & - & 1.16 & - & - & - \\
\hline Ir & 7.13 & 7.02 & 20.75 & 5.61 & 6.10 & 37.12 & 37.00 & 36.60 & 34.42 & 33.62 \\
\hline $\mathbf{R u}$ & 9.73 & 9.54 & 10.42 & 23.97 & 23.62 & 0.98 & 3.09 & 0.18 & - & - \\
\hline $\mathrm{Rh}$ & 0.47 & 0.41 & 0.35 & 0.97 & 0.76 & 7.47 & 7.24 & 6.98 & 4.12 & 4.30 \\
\hline $\mathrm{Pt}$ & - & - & - & - & - & 3.65 & 4.50 & 1.95 & - & - \\
\hline Pd & - & - & 0.21 & 0.18 & - & 0.24 & 0.03 & - & 0.04 & - \\
\hline As & - & - & - & - & - & - & - & - & - & - \\
\hline $\mathrm{Ni}$ & 0.05 & 0.06 & - & - & - & 6.31 & 3.44 & 10.25 & 10.96 & 10.66 \\
\hline $\mathrm{Cu}$ & - & - & - & - & - & 6.88 & 8.38 & 5.64 & 5.43 & 10.11 \\
\hline $\mathrm{Fe}$ & 1.43 & 1.31 & 0.78 & 0.45 & 0.54 & 5.08 & 2.89 & 7.37 & 11.86 & 11.65 \\
\hline $\mathrm{Cr}$ & 5.77 & 5.02 & 3.84 & 3.52 & 2.23 & 2.87 & 2.63 & 3.59 & 2.96 & 2.21 \\
\hline Total & 92.45 & 94.02 & 92.61 & 95.43 & 98.53 & 96.97 & 96.13 & 99.44 & 95.36 & 99.23 \\
\hline At $\%$ & & & & & & & & & & \\
\hline$S$ & 68.04 & 68.05 & 50.07 & 68.34 & 67.09 & 57.70 & 58.74 & 55.75 & 53.04 & 52.07 \\
\hline Os & 18.27 & 18.92 & 24.37 & 11.29 & 12.92 & - & 0.44 & - & - & - \\
\hline Ir & 3.09 & 2.99 & 11.97 & 2.08 & 2.24 & 13.55 & 14.06 & 12.66 & 11.94 & 10.95 \\
\hline $\mathbf{R u}$ & 8.02 & 7.71 & 11.43 & 16.93 & 16.49 & 0.68 & 2.23 & 0.12 & - & - \\
\hline Rh & 0.38 & 0.33 & 0.38 & 0.67 & 0.52 & 5.09 & 5.14 & 4.51 & 2.67 & 2.61 \\
\hline $\mathbf{P t}$ & - & - & - & - & - & 1.31 & 1.68 & 0.67 & - & - \\
\hline Pd & - & - & 0.22 & 0.12 & - & 0.16 & 0.02 & - & 0.02 & - \\
\hline As & - & - & - & - & - & - & - & - & - & - \\
\hline $\mathrm{Ni}$ & 0.07 & 0.08 & - & - & - & 7.54 & 4.28 & 11.61 & 12.46 & 11.37 \\
\hline $\mathrm{Cu}$ & - & - & - & - & - & 7.59 & 9.63 & 5.91 & 5.70 & 9.96 \\
\hline $\mathrm{Fe}$ & 2.13 & 1.92 & 1.55 & 0.57 & 0.68 & 6.38 & 3.77 & 8.77 & 14.16 & 13.05 \\
\hline
\end{tabular}

S. No.: sample numbers. Sample 29 is related to MTZ chromitite, samples 11,18 and 43 are related to PGE-poor chromitite, and samples 67 and 68 are related to PGE-rich chromitite. Electron-microprobe data. 
TABLE 3. REPRESENTATIVE COMPOSITIONS OF PGE SULFARSENIDE AND ARSENIDE IN CHROMITITE, OMAN OPHIOLITE

\begin{tabular}{|c|c|c|c|c|c|c|c|c|c|c|c|}
\hline \multirow{2}{*}{$\begin{array}{l}\text { Wt \% } \\
\text { S. No. }\end{array}$} & \multicolumn{2}{|c|}{ Irarsite } & \multicolumn{2}{|c|}{ Hollingworthite } & \multicolumn{6}{|c|}{ Irarsite-hollingworthite } & \multirow{2}{*}{$\begin{array}{c}P d \text { arsenide } \\
23-4 \\
\end{array}$} \\
\hline & $41-3$ & $41-4$ & $68-5$ & $68-6$ & $26-1$ & $68-1$ & $68-2$ & $68-3$ & $23-2$ & $23-3$ & \\
\hline $\mathrm{S}$ & 13.63 & 12.66 & 15.35 & 15.48 & 11.92 & 12.96 & 12.92 & 13.21 & 12.39 & 12.41 & 0.06 \\
\hline Os & 1.22 & 0.86 & 0.41 & 0.61 & - & - & - & - & - & - & - \\
\hline Ir & 46.25 & 45.56 & 5.07 & 6.38 & 40.60 & 43.01 & 44.13 & 45.38 & 28.90 & 29.21 & 0.36 \\
\hline $\mathrm{Ru}$ & 2.58 & 1.89 & - & 0.21 & 0.98 & 0.54 & 0.80 & 1.20 & 0.28 & 0.02 & - \\
\hline $\mathrm{Rh}$ & 1.59 & 1.41 & 41.08 & 41.30 & 9.99 & 11.86 & 11.14 & 9.76 & 19.97 & 20.34 & 0.14 \\
\hline Pt & - & - & 3.83 & 3.24 & 0.42 & 1.27 & 0.60 & 0.28 & 5.30 & 5.48 & 0.79 \\
\hline $\mathrm{Pd}$ & - & 0.03 & 0.23 & 0.04 & 0.26 & 0.30 & 0.06 & 0.27 & 0.29 & - & 72.87 \\
\hline As & 27.50 & 28.28 & 32.42 & 31.64 & 19.41 & 28.23 & 28.42 & 27.57 & 27.71 & 27.80 & 22.04 \\
\hline $\mathrm{Ni}$ & 0.03 & 0.03 & 0.18 & 0.10 & 0.05 & - & - & - & 0.09 & 0.09 & 0.04 \\
\hline $\mathrm{Cu}$ & - & - & - & - & 6.21 & 0.03 & 0.10 & 0.62 & 0.01 & - & 1.06 \\
\hline $\mathrm{Fe}$ & 0.45 & 0.26 & 0.15 & 0.15 & 1.70 & 0.71 & 0.47 & 0.49 & 0.27 & 0.35 & 0.24 \\
\hline $\mathrm{Cr}$ & 1.95 & 2.34 & 1.42 & 1.31 & 5.50 & 1.96 & 1.20 & 1.22 & 0.56 & 0.76 & 0.62 \\
\hline Total & 95.20 & 93.35 & 100.14 & 100.76 & 97.04 & 100.87 & 99.84 & 100.00 & 95.76 & 96.46 & 98.22 \\
\hline At $\%$ & & & & & & & & & & & \\
\hline $\mathrm{S}$ & 39.33 & 37.70 & 35.03 & 35.33 & 34.34 & 35.21 & 35.29 & 35.97 & 33.90 & 33.84 & 0.19 \\
\hline Os & 0.59 & 0.43 & 0.16 & 0.24 & & - & & & - & - & 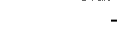 \\
\hline Ir & 22.27 & 22.63 & 1.93 & 2.43 & 19.52 & 19.50 & 20.12 & 20.62 & 13.19 & 13.29 & 0.19 \\
\hline Ru & 2.36 & 1.78 & - & 0.15 & 0.90 & 0.47 & 0.70 & 1.03 & 0.24 & 0.02 & - \\
\hline $\mathrm{Rh}$ & 1.43 & 1.31 & 29.21 & 29.37 & 8.97 & 10.04 & 9.48 & 8.28 & 17.03 & 17.28 & 0.13 \\
\hline $\mathrm{Pt}$ & - & - & 1.43 & 1.22 & 0.20 & 0.57 & 0.27 & 0.12 & 2.38 & 2.46 & 0.40 \\
\hline Pd & - & 0.05 & 0.15 & 0.03 & 0.23 & 0.24 & 0.05 & 0.22 & 0.24 & - & 67.82 \\
\hline As & 33.97 & 36.04 & 31.66 & 30.91 & 23.93 & 32.83 & 33.23 & 32.13 & 32.45 & 32.44 & 29.13 \\
\hline $\mathrm{Ni}$ & 0.05 & 0.05 & 0.23 & 0.13 & 0.08 & - & - & - & 0.13 & 0.13 & 0.07 \\
\hline $\mathrm{Cu}$ & - & - & 0 & 0 & 9.03 & 0.04 & 0.14 & 0.85 & 0.01 & - & 1.65 \\
\hline $\mathrm{Fe}$ & 0.75 & 0.44 & 0.20 & 0.20 & 2.81 & 1.10 & 0.73 & 0.77 & 0.42 & 0.55 & 0.43 \\
\hline
\end{tabular}

S. No.: sample numbers. Samples 23, 26 and 41 are related to PGE-poor chromitite, whereas sample 68 is related to PGE-rich chromitite. Electron-microprobe data.

TABLE 4. REPRESENTATIVE COMPOSITIONS OF PGE ALLOYS IN CHROMITITE, OMAN OPHIOLITE

\begin{tabular}{|c|c|c|c|c|c|c|c|c|c|c|}
\hline \multirow{2}{*}{$\begin{array}{l}\text { Wt \% } \\
\text { S. No. }\end{array}$} & \multicolumn{2}{|c|}{ Os-Ir } & \multicolumn{2}{|c|}{ Cu-Pt-Ir-Fe-Rh } & \multicolumn{2}{|c|}{ Ni-Ru-Os-Ir } & \multirow{2}{*}{$\begin{array}{c}\mathrm{Pt}-\mathrm{Fe} \\
23-1\end{array}$} & \multirow{2}{*}{$\begin{array}{c}\text { Ir-Rh } \\
68-5\end{array}$} & \multirow{2}{*}{$\begin{array}{l}\text { Ir-Pt } \\
67-4\end{array}$} & \multirow{2}{*}{$\begin{array}{c}\text { Pd metal } \\
23-1\end{array}$} \\
\hline & $11-2$ & $68-8$ & $26-1$ & $26-2$ & $43-3$ & $43-4$ & & & & \\
\hline $\mathrm{S}$ & - & - & 0.08 & - & 0.05 & - & 0.04 & - & - & 0.13 \\
\hline Os & 53.72 & 68.81 & - & - & 18.38 & 17.17 & - & - & 3.13 & 0.22 \\
\hline Ir & 36.37 & 14.46 & 12.71 & 12.80 & 7.81 & 8.05 & 0.30 & 57.31 & 16.66 & 0.51 \\
\hline $\mathrm{Ru}$ & 1.20 & 0.60 & - & & 21.88 & 20.28 & 0.04 & 1.40 & 4.54 & - \\
\hline $\mathrm{Rh}$ & 0.16 & 0.14 & 8.80 & 12.41 & 0.54 & 0.54 & 0.60 & 12.67 & 1.61 & 0.24 \\
\hline Pt & - & - & 28.72 & 25.11 & - & - & 82.12 & - & 11.28 & 1.57 \\
\hline Pd & 0.47 & 0.15 & 0.19 & 0.38 & - & 0.11 & 5.52 & - & 0.04 & 87.59 \\
\hline As & - & - & - & - & - & - & 0.15 & - & - & 0.68 \\
\hline $\mathrm{Ni}$ & - & - & 0.17 & 0.11 & 32.99 & 38.01 & 0.43 & 3.16 & 0.11 & 0.10 \\
\hline $\mathrm{Cu}$ & - & - & 25.40 & 23.59 & 0.20 & 0.51 & 3.26 & 1.19 & - & 0.05 \\
\hline $\mathrm{Fe}$ & 0.68 & 0.72 & 7.36 & 11.26 & 2.12 & 2.26 & 10.02 & 2.31 & 6.06 & 0.50 \\
\hline $\mathrm{Cr}$ & 2.25 & 6.70 & 2.41 & 2.16 & 4.31 & 3.02 & 1.17 & 4.05 & 19.84 & 0.78 \\
\hline Total & 94.85 & 91.58 & 85.85 & 87.83 & 88.26 & 89.96 & 103.64 & 82.29 & 63.27 & 92.35 \\
\hline At $\%$ & & & & & & & & & & \\
\hline$S$ & - & - & 0.30 & - & 0.15 & - & 0.17 & - & - & 0.47 \\
\hline Os & 56.33 & 78.92 & & - & 10.04 & 8.73 & - & - & 4.95 & 0.13 \\
\hline Ir & 37.70 & 16.39 & 7.90 & 7.45 & 4.22 & 4.05 & 0.22 & 54.31 & 26.07 & 0.31 \\
\hline Ru & 2.37 & 1.29 & & - & 22.45 & 19.37 & 0.05 & 2.52 & 13.51 & - \\
\hline $\mathrm{Rh}$ & 0.32 & 0.29 & 10.21 & 13.49 & 0.54 & 0.51 & 0.81 & 22.42 & 4.70 & 0.27 \\
\hline $\mathrm{Pt}$ & & - & 17.58 & 14.40 & - & - & 58.32 & - & 17.38 & 0.93 \\
\hline $\mathrm{Pd}$ & 0.88 & 0.32 & 0.21 & 0.40 & - & 0.10 & 7.19 & - & 0.12 & 95.50 \\
\hline As & - & - & - & - & - & & 0.28 & - & - & 1.05 \\
\hline $\mathrm{Ni}$ & - & - & 0.35 & 0.21 & 58.33 & 62.55 & 1.02 & 9.80 & 0.55 & 0.20 \\
\hline $\mathrm{Cu}$ & - & - & 47.72 & 41.51 & 0.33 & 0.78 & 7.11 & 3.42 & - & 0.09 \\
\hline $\mathrm{Fe}$ & 2.41 & 2.79 & 15.73 & 22.55 & 3.94 & 3.91 & 24.84 & 7.53 & 32.71 & 1.04 \\
\hline
\end{tabular}

S. No.: sample numbers. Samples 11,67 and 68 are related to PGE-rich chromitite, whereas samples 23,26 and 43 are related to PGE-poor chromitite. Electron-microprobe data. 
In grains of the unidentified $\mathrm{Cu}-\mathrm{Pt}-\mathrm{Fe}-\mathrm{Ir}-\mathrm{Rh}$ alloy, the Pt content may reach $28.7 \mathrm{wt} \%$, and the mineral also contains considerable amounts of $\mathrm{Cu}$ (up to $25.4 \mathrm{wt} \%$ ), $\mathrm{Fe}$ (up to $11.3 \mathrm{wt} \%$ ), Ir (up to $12.8 \mathrm{wt} \%$ ) and $\mathrm{Rh}$ (up to $12.4 \mathrm{wt} \%$ ) (Table 4). The average chemical formula of this mineral is $\left(\mathrm{Cu}_{0.45} \mathrm{Fe}_{0.19} \mathrm{Pt}_{0.16} \mathrm{Rh}_{0.12} \mathrm{Ir}_{0.08}\right)$ (Table 4). This mineral most likely represents a PGE-rich basemetal alloy or desulfurized PGE-rich base-metal sulfide, e.g., chalcopyrite. The unidentified $\mathrm{Ni}-\mathrm{Ru}-\mathrm{Os}-\mathrm{Ir}$ alloy $\left(\mathrm{Ni}_{0.61} \mathrm{Ru}_{0.22} \mathrm{Os}_{0.09} \mathrm{Ir}_{0.04} \mathrm{Fe}_{0.04}\right)$, also appears to be PGErich desulfurized base-metal sulfide, e.g., millerite. The PGE $(\mathrm{Ru}+\mathrm{Os}+\mathrm{Ir})$ to base metal $(\mathrm{Ni}+\mathrm{Fe})$ ratio is approximately 1:2 (Table 4).

Small grains of possible Ir-Pt and Ir-Rh alloys are found to be associated with Os-rich laurite within chromian spinel of the PGE-rich chromitite (Table 4). The Ir-Pt alloy contains up to $4.5 \mathrm{wt} \% \mathrm{Ru}, 3.1 \mathrm{wt} \% \mathrm{Os}$, and $1.6 \mathrm{wt} \% \mathrm{Rh}$. The very low total and high amounts of $\mathrm{Cr}$ and $\mathrm{Fe}$ are due to the small grain-size. The Ir-Rh alloy contains considerable amounts of $\mathrm{Cu}, \mathrm{Ni}$ and $\mathrm{Fe}$.

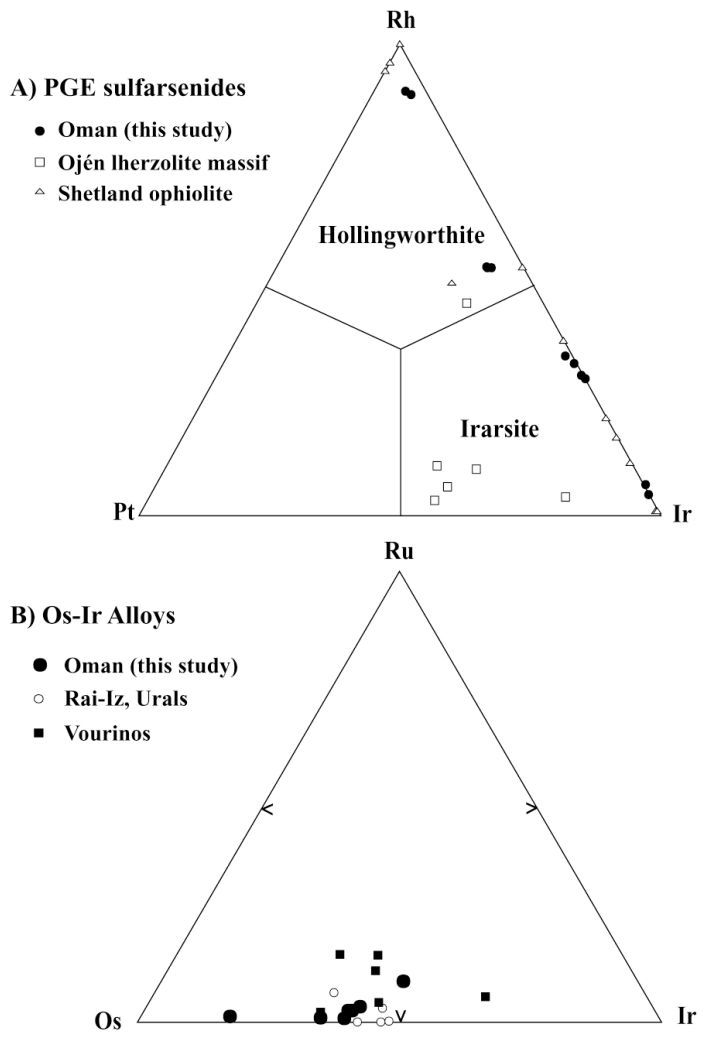

FIG. 8. Compositional variation of PGE sulfarsenides in terms of (A) Rh-Pt-Ir and (B) Ru-Os-Ir of Os-Ir alloy from the northern Oman chromitites (atom proportions).
Its formula $\left(\mathrm{Ir}_{0.54} \mathrm{Rh}_{0.22} \mathrm{Ru}_{0.03} \mathrm{Ni}_{0.10} \mathrm{Fe}_{0.08} \mathrm{Cu}_{0.03}\right)$ shows an approximate PGE : base metal ratio of about 4:1 (Table 4). The Pt-Fe alloy and native Pd metal are found as parts of a composite PGM grain in fractures in spinel in the PGE-poor chromitite (Table 4). They are found intergrown around a grain of irarsite. The $\mathrm{Pt}-\mathrm{Fe}$ alloy contains various amounts of $\mathrm{Pd}, \mathrm{Cu}$ and $\mathrm{Ni}$, and has a formula $\left(\mathrm{Pt}_{0.60} \mathrm{Fe}_{0.25} \mathrm{Pd}_{0.07} \mathrm{Cu}_{0.07} \mathrm{Ni}_{0.01}\right)$, comparable to isoferroplatinum $\left(\mathrm{Pt}_{3} \mathrm{Fe}\right)$ reported by Cabri (1981).

\section{Oxide}

The PGE oxides or hydroxides documented so far in the literature are mostly enriched in Pt and Pd, which are more mobile than $\mathrm{Ru}$, Os and Ir, and are found mainly in alluvial occurrences (e.g., Augé \& Legendre 1994). However, in situ PGE oxides or hydroxides of $\mathrm{Ru}-\mathrm{Os}-\mathrm{Ir}$ have been recently described from chromitite (e.g., Augé \& Legendre 1994, Garuti \& Zaccarini 1997, Garuti et al. 1997). The chemical analysis of the PGE oxide in the northern Oman chromitite demonstrates the exclusive presence of $\mathrm{Ru}$, Os and Ir as major constituents, with a considerable amount of $\mathrm{Fe}$, and traces of $\mathrm{Ni}$ and $\mathrm{Rh}$ (Table 5). The analytical totals are much less than $100 \mathrm{wt} \%$, which is ascribed to the possible presence of some light elements not determined by electronmicroprobe analysis. We sought the anions, such as $\mathrm{S}$, $\mathrm{As}, \mathrm{Te}, \mathrm{Bi}$ and $\mathrm{Sb}$, but they are practically absent.

Wavelength-dispersion spectroscopy (WDS) clearly shows that oxygen is one of the major constituents in these PGM (Ahmed et al. 2002). The average chemical formula of the PGE oxide is $\left(\mathrm{Ru}_{0.57} \mathrm{Os}_{0.16} \mathrm{Ir}_{0.07} \mathrm{Fe}_{0.16}\right.$ $\left.\mathrm{Rh}_{0.02} \mathrm{Ni}_{0.02}\right)_{\Sigma_{2}} \mathrm{O}$. The possible presence of hydroxyl $(\mathrm{OH})$ cannot be eliminated. The PGE oxide is within the compositional range of Os-rich laurite in terms of $\mathrm{Ru}-\mathrm{Os}-\mathrm{Ir}$ proportions (Fig. 9). A Ru-Os-Ir oxide similar to the one we found was reported by Garuti \& Zaccarini (1997) and Garuti et al. (1997) from altered or weathered chromitites. The O-bearing PGM from weathered (lateritized) samples, in which limonite and other Fe hydroxides are abundant, are possibly a mixture of a PGE alloy and Fe hydroxide (e.g., Garuti \& Zaccarini 1997). The relatively low content of $\mathrm{Fe}$ in the Oman PGE oxide may indicate that the oxygen detected was not derived from an admixed Fe hydroxide (Ahmed et al. 2002). More details about the composition of PGE oxide are presented in Ahmed et al. (2002).

\section{Base-metal sulfides and alloys}

Almost all base-metal sulfides (BMS) and basemetal alloys (BMA) have trace amounts of PGE (up to $0.7 \mathrm{wt} \%$ ) except for bornite, which has up to $6.9 \mathrm{wt} \%$ of total PGE (Table 6). The most abundant BMA is Ni-Fe alloy, which displays large aggregates and anhedral grains with a pitted and rough appearance. The alloy is usually found in the PGE-poor chromitite as inclusions within altered parts of chromian spinel. The $\mathrm{Ni}-\mathrm{Fe}$ al- 


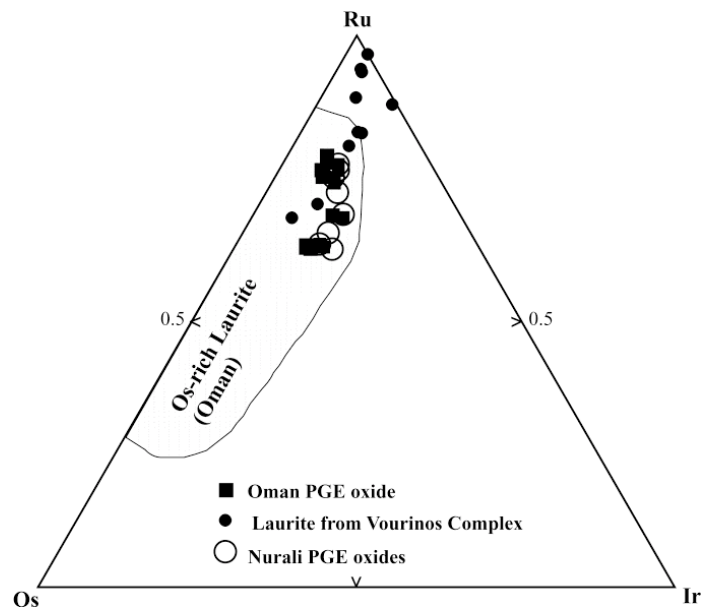

FIG. 9. Compositional variation of oxide-hydroxide grains in terms of Ru-Os-Ir (in atomic ratios) in the PGE-mineralized chromitite, Oman ophiolite, in comparison with Osrich laurite from the northern Oman chromitites, PGE oxides from the Nurali ultramafic complex, southern Urals, Russia (Garuti et al. 1997), and laurite of Vourinos complex (Augé 1988). Note the similarity in element proportions between the PGE oxide and laurite from Oman, and between the PGE oxides of Oman and the Nurali complex. loy has an average chemical composition typical of awaruite $\left(\mathrm{Ni}_{3} \mathrm{Fe}\right)$ (Table 6). Awaruite associated with $\mathrm{Ni}$ sulfides has been described from serpentinized ultramafic rocks and is usually considered to be of secondary origin (e.g., Melcher et al. 1997, Bai et al. 2000). Pentlandite, $\left(\mathrm{Ni}_{0.31} \mathrm{Fe}_{0.21}\right) \mathrm{S}_{0.48}$ on average, has a metal:sulfur ratio of approximately 1 (Table 6). The unidentified $\mathrm{Cu}$-rich $\mathrm{Ni}-\mathrm{Fe}$ sulfide found in our PGEpoor and MTZ chromitites usually has a pentlanditetype metal:sulfur ratio, with a composition $\left(\mathrm{Ni}_{0.37} \mathrm{Fe}_{0.08}\right.$ $\left.\mathrm{Cu}_{0.05}\right) \mathrm{S}_{0.50}$ on average, and up to $8.40 \mathrm{wt} \% \mathrm{Cu}$ (Table 6). A Cu-rich Ni-Fe sulfide with a similar composition has also been reported as inclusions in spinel and as a matrix mineral in relatively altered chromitite (Augé 1988, Ferrario \& Garuti 1990). It has also been described from the sulfide-rich chromitite of the MoaBarracoa ophiolite massif, eastern Cuba (Proenza et al. 2001). Millerite contains various amounts of $\mathrm{Fe}$, from 0.8 to $11.4 \mathrm{wt} \%$, and has an average chemical formula $\left(\mathrm{Ni}_{0.44} \mathrm{Fe}_{0.05}\right) \mathrm{S}_{0.51}$ (Table 6). The metal $(\mathrm{Cu}+\mathrm{Fe})$ to sulfur ratio of bornite is approximately $6: 4$, and its average formula is $\left(\mathrm{Cu}_{0.51} \mathrm{Fe}_{0.07}\right) \mathrm{S}_{0.42}$, which is close to the ideal formula, $\mathrm{Cu}_{5} \mathrm{FeS}_{4}$. The relatively high $\mathrm{Os}$, Ir and $\mathrm{Ru}$ contents in some grains of bornite may be derived from adjacent Os-rich laurite (Table 6). Heazlewoodite is the

TABLE 5. REPRESENTATIVE COMPOSITIONS OF THE PGE OXIDES IN CHROMITITE, OMAN OPHIOLITE

\begin{tabular}{|c|c|c|c|c|c|c|c|c|}
\hline \multirow{2}{*}{$\begin{array}{l}\text { Wt } \% \\
\text { S. No. }\end{array}$} & \multicolumn{4}{|c|}{ Analysis without oxygen } & \multicolumn{4}{|c|}{ Analysis with oxygen } \\
\hline & $18-6$ & $18-7$ & $6-2$ & $18-5^{*}$ & $18-6$ & $18-7$ & $6-2$ & $18-5^{*}$ \\
\hline $\mathrm{O}$ & - & - & - & - & 10.32 & 7.65 & 6.14 & 0.20 \\
\hline$S$ & 0.02 & - & 0.02 & 32.12 & 0.02 & - & 0.02 & 32.12 \\
\hline Os & 25.75 & 25.74 & 15.35 & 22.07 & 25.75 & 25.74 & 15.35 & 22.07 \\
\hline Ir & 11.71 & 12.02 & 6.76 & 11.83 & 11.71 & 12.02 & 6.76 & 11.83 \\
\hline $\mathrm{Ru}$ & 34.57 & 34.13 & 42.97 & 28.03 & 34.57 & 34.13 & 42.97 & 28.03 \\
\hline $\mathrm{Rh}$ & 1.10 & 1.04 & 1.37 & 0.70 & 1.11 & 1.04 & 1.37 & 0.70 \\
\hline Pt & - & - & - & - & - & - & - & - \\
\hline Pd & 0.12 & - & 0.11 & 0.01 & 0.12 & - & 0.11 & 0.01 \\
\hline As & - & - & - & - & - & - & - & - \\
\hline $\mathrm{Ni}$ & 1.19 & 2.03 & 0.18 & 0.09 & 1.19 & 2.03 & 0.18 & 0.09 \\
\hline $\mathrm{Cu}$ & - & - & - & - & - & - & - & \\
\hline $\mathrm{Fe}$ & 4.31 & 3.39 & 6.39 & 0.52 & 4.31 & 3.39 & 6.39 & 0.52 \\
\hline $\mathrm{Cr}$ & 3.23 & 1.98 & 1.53 & 1.72 & 3.23 & 1.98 & 1.53 & 1.72 \\
\hline Total & 82.00 & 80.23 & 74.68 & 97.09 & 92.33 & 88.56 & 80.79 & 97.29 \\
\hline At $\%$ & & & & & & & & \\
\hline o & & & & & 49.88 & 42.33 & 36.29 & 0.84 \\
\hline$S$ & 0.09 & - & 0.09 & 67.94 & 0.04 & - & 0.06 & 67.37 \\
\hline Os & 20.91 & 20.80 & 12.00 & 7.88 & 10.48 & 11.99 & 7.64 & 7.81 \\
\hline Ir & 9.40 & 9.60 & 5.23 & 4.17 & 4.71 & 5.54 & 3.33 & 4.14 \\
\hline $\mathrm{Ru}$ & 52.75 & 51.82 & 63.14 & 18.80 & 26.44 & 29.89 & 40.22 & 18.65 \\
\hline Rh & 1.64 & 1.55 & 1.97 & 0.46 & 0.82 & 0.90 & 1.26 & 0.46 \\
\hline $\mathrm{Pt}$ & - & - & - & & - & - & - & - \\
\hline Pd & 0.17 & - & 0.14 & 0.01 & 0.09 & - & 0.09 & 0.01 \\
\hline As & - & - & - & - & - & - & - & - \\
\hline $\mathrm{Ni}$ & 3.12 & 5.31 & 0.46 & 0.10 & 1.56 & 3.06 & 0.29 & 0.10 \\
\hline $\mathrm{Cu}$ & - & - & - & - & - & - & - & - \\
\hline $\mathrm{Fe}$ & 11.92 & 10.92 & 16.99 & 0.63 & 5.97 & 6.30 & 10.82 & 0.63 \\
\hline
\end{tabular}

S. No.: sample numbers. Sample 18 is related to PGE-poor chromitite, whereas sample 6 is related to PGE-poor chromitite. Electronmicroprobe data. * Grain of Os-rich laurite. 
TABLE 6. REPRESENTATIVE COMPOSITIONS OF BASE-METAL SULFIDES (BMS) AND BASE-METAL ALLOY (BMA) IN CHROMITITE, OMAN OPHIOLITE

\begin{tabular}{|c|c|c|c|c|c|c|c|c|c|c|c|}
\hline \multirow{2}{*}{$\begin{array}{l}\text { Wt \% } \\
\text { S. No. }\end{array}$} & \multicolumn{2}{|c|}{ Pentlandite } & \multicolumn{2}{|c|}{$\begin{array}{c}\text { Cu-rich } \\
\text { pentlandite }\end{array}$} & \multicolumn{2}{|c|}{ Millerite } & \multicolumn{2}{|c|}{$\begin{array}{l}\mathrm{Ni}-\mathrm{Fe} \text { alloy } \\
\text { (Awaruite) }\end{array}$} & \multicolumn{2}{|c|}{ Bornite } & \multirow{2}{*}{$\begin{array}{c}\text { Heazlewoodite } \\
29 \\
\end{array}$} \\
\hline & 60 & 30 & $29-1$ & $29-2$ & 20 & 60 & $43-2$ & $43-1$ & $43-1$ & $43-1$ & \\
\hline$S$ & 32.18 & 33.49 & 34.94 & 32.03 & 35.08 & 33.23 & 0.06 & 0.01 & 23.05 & 22.76 & 27.33 \\
\hline Os & 0.27 & - & 0.27 & 0.12 & 0.08 & 0.08 & 0.11 & 0.18 & 3.30 & 1.89 & 0.33 \\
\hline Ir & 0.05 & 0.03 & - & 0.14 & 0.06 & 0.01 & 0.05 & 0.06 & 1.86 & 0.53 & 0.04 \\
\hline $\mathrm{Ru}$ & - & 0.10 & 0.02 & 0.28 & 0.02 & 0.13 & 0.16 & 0.01 & 3.52 & 0.98 & 0.11 \\
\hline $\mathrm{Rh}$ & 0.02 & 0.11 & 0.02 & 0.11 & - & 0.02 & 0.03 & 0.13 & 0.14 & 0.06 & - \\
\hline $\mathrm{Pt}$ & - & 0.02 & - & - & - & 0.06 & - & - & - & - & - \\
\hline $\mathrm{Pd}$ & - & - & - & 0.03 & 0.10 & 0.16 & - & 0.05 & 0.14 & 0.13 & 0.15 \\
\hline As & - & - & - & - & - & - & - & - & - & - & - \\
\hline $\mathrm{Ni}$ & 33.66 & 38.15 & 47.90 & 42.07 & 61.48 & 52.49 & 71.00 & 74.28 & 0.41 & 0.09 & 69.87 \\
\hline $\mathrm{Cu}$ & - & 0.21 & 6.47 & 8.32 & 0.29 & 0.02 & 1.28 & 0.27 & 56.43 & 53.16 & 0.30 \\
\hline $\mathrm{Fe}$ & 29.25 & 26.35 & 9.03 & 17.22 & 0.81 & 7.97 & 21.19 & 24.20 & 5.29 & 8.67 & 0.98 \\
\hline $\mathrm{Cr}$ & 3.43 & 1.71 & 2.28 & 3.97 & 1.66 & 2.68 & 3.26 & 1.85 & 2.76 & 4.27 & 1.51 \\
\hline Total & 98.87 & 100.17 & 100.94 & 104.29 & 99.58 & 96.84 & 97.14 & 101.03 & 96.88 & 92.54 & 100.62 \\
\hline At $\%$ & & & & & & & & & & & \\
\hline $\mathbf{S}$ & 47.72 & 48.09 & 50.19 & 46.23 & 50.59 & 49.89 & 0.12 & 0.01 & 40.55 & 41.10 & 41.19 \\
\hline Os & 0.07 & - & 0.07 & 0.03 & 0.02 & 0.02 & 0.04 & 0.06 & 0.98 & 0.57 & 0.08 \\
\hline Ir & 0.01 & 0.01 & - & 0.03 & 0.01 & - & 0.01 & 0.02 & 0.55 & 0.16 & 0.01 \\
\hline $\mathrm{Ru}$ & - & 0.05 & 0.01 & 0.13 & 0.01 & 0.06 & 0.10 & 0.01 & 1.96 & 0.56 & 0.05 \\
\hline Rh & 0.01 & 0.05 & 0.01 & 0.05 & - & 0.01 & 0.02 & 0.07 & 0.07 & 0.04 & - \\
\hline $\mathrm{Pt}$ & - & 0.01 & - & - & - & 0.01 & - & - & - & - & - \\
\hline $\mathrm{Pd}$ & - & - & - & 0.01 & 0.04 & 0.07 & - & 0.03 & 0.08 & 0.07 & 0.07 \\
\hline As & - & - & - & - & - & - & - & - & - & - & - \\
\hline $\mathrm{Ni}$ & 27.28 & 29.92 & 37.59 & 33.18 & 48.44 & 43.05 & 74.96 & 74.17 & 0.39 & 0.09 & 57.52 \\
\hline $\mathrm{Cu}$ & - & 0.15 & 4.69 & 6.06 & 0.21 & 0.02 & 1.25 & 0.25 & 50.09 & 48.43 & 0.22 \\
\hline $\mathrm{Fe}$ & 24.91 & 21.72 & 7.45 & 14.27 & 0.67 & 6.87 & 23.51 & 25.39 & 5.34 & 8.99 & 0.85 \\
\hline
\end{tabular}

S. No.: sample numbers. Samples 20,29,30 and 60 are related to MTZ chromitite, whereas sample 43 is related to the PGE-poor chromitite. Electron-microprobe data.

least abundant BMS; it is restricted to the interstitial matrix of the MTZ chromitite. It has very low levels of $\mathrm{Fe}$ and $\mathrm{Cu}$ (Table 6), and its average chemical formula is $\left(\mathrm{Ni}_{0.42} \mathrm{~S}_{0.58}\right)$.

\section{DISCUSSION}

\section{The Oman ophiolite among others: a comparison}

After the discovery of unusually high-PGE chromitite, the consensus that the Oman ophiolite is one of the classical PGE-poor ophiolites of the world (e.g., Augé 1986, Prichard et al. 1996a) must be revisited. Although most chromitites in ophiolites contain between 100 and $500 \mathrm{ppb}$ of PGE and have moderate to low $\mathrm{Pd} / \mathrm{Ir}$ values (0.8-0.1) (Leblanc 1991), PGE-rich (>750 ppb) chromitites with very low Pd/Ir values $(<0.1)$ have been described from some ophiolites, such as the Massif du Sud in New Caledonia (Page et al. 1982a). The PGE contents of our PGE-rich chromitite (1500 ppb) with an extremely low Pd/Ir value (0.007) (Ahmed \& Arai 2002) now place parts of the Oman ophiolite among the most PGE-enriched of ophiolite complexes.

According to the literature, two types of PGE distributions have been found in the mantle section of ophiolites: (1) a unimodal distribution characterized by
(Ru-Os-Ir)-dominant PGM, and (2) a bimodal distribution characterized by ( $\mathrm{Ru}-\mathrm{Os}-\mathrm{Ir}$ )-bearing chromitites in the deeper mantle section and (Rh-Pt-Pd)-bearing chromitites in the uppermost part of the mantle section, near the MTZ. The former type is occasionally linked to the deep-seated mantle chromitites in ophiolites such as Vourinos, Greece (Augé 1988, Garuti \& Zaccarini 1997), Rhodope, Bulgaria (Tarkian et al. 1991), Skyros Island, Greece (Tarkian et al. 1992) and Othrys, Greece (Garuti et al. 1999a). The latter type has been reported from ophiolites such as Zambales, the Philippines (Bacuta et al. 1988), Thetford Mines, Canada (Corrivaux \& Laflamme 1990), Bulqiza and Tropoja, Albania (Ohnenstetter et al. 1991), Pindos, Greece (Tarkian et al. 1996), and Shetland (Prichard et al. 1996b).

The Oman ophiolite belongs the "unimodal" type: the (Ru,Os,Ir)-bearing chromitites are common both in the deeper mantle section and in the MTZ. Laurite, by far the most common primary PGM in the northern Oman chromitites, is accompanied by minor amounts of other PGM: erlichmanite as in Othrys (Garuti et al. 1999a), an Os-Ir alloy as in Vourinos (Augé 1988), an unnamed Ir-rich sulfide as in Ojén, Spain (Garuti et al. 1995), and a PGE sulfarsenide as in many other complexes (e.g., Augé 1988, Legendre \& Augé 1986, Thalhammer \& Stumpfl 1988, Tarkian et al. 1991). The 
combination of these types of minerals in chromitites of the northern Oman ophiolitic complex suggests that crystallization occurred where sulfur was widely variable. The presence of a PGE oxide is also comparable to what has been reported in some localities (e.g., Augé \& Legendre 1994, Garuti \& Zaccarini 1997, Garuti et al. 1997), and ascribed to the desulfurization of primary PGM, i.e., laurite, during an early stage of serpentinization.

In terms of laurite composition, the Oman ophiolite is similar to the Othrys ophiolite, Greece (Garuti et al. 1999a), the Rai-Iz ophiolite, Polar Urals, Russia (Garuti et al. 1999b), and to the Finero and Ojén peridotite complexes (Ferrario \& Garuti 1990, Garuti et al. 1995). In these complexes, laurite is usually Os- and somewhat Ir-rich, and has an apparent compositional gap with erlichmanite (Fig. 10). On the other hand, the laurite composition of the Oman ophiolite is quite different from those in some ophiolites and layered intrusions, i.e., New Caledonia (Augé \& Maurizot 1995) and Vourinos (Augé 1988) ophiolites, Stillwater Complex, Montana (Talkington \& Lipin 1986), and the Bird River Sill complex, Manitoba (Ohnenstetter et al. 1986). The laurite in these complexes is usually $\mathrm{Ru}$-rich and Osand Ir-poor relative to those of the first group (Fig. 10). There is a clear contrast between the Ru-rich laurite in all of the stratiform chromitites and some podiform chromitites and the Os-rich laurite in the other type of podiform chromitite.

\section{Origin of primary PGM assemblages}

The PGE sulfides and Os-Ir alloy mainly found included in fresh chromian spinel are typically interpreted as primary phases (e.g., Stockman \& Hlava 1984, Augé 1988, Melcher et al. 1997, Garuti et al. 1999a, b, Bai et al. 2000). They are probably produced as early precipitates from the melt involved in chromitite formation. There is now a broad agreement that the PGM inclusions represent magmatic minerals entrapped by crystals of chromian spinel (e.g., Stockman \& Hlava 1984, Augé 1988, Ferrario \& Garuti 1990, Torres-Ruiz et al. 1996) rather than the products of subsolidus exsolution from the host chromian spinel (e.g., Naldrett \& Cabri 1976). The composition of Os-rich laurite in the three types of chromitite from Oman, i.e., mantle PGE-rich, mantle PGE-poor and MTZ, is virtually identical, suggesting no dependency on the host composition of chromian spinel. Furthermore, the perfect euhedral shape of the laurite crystals and their sporadic distribution even within the same pod strongly suggest that laurite represents a high-temperature phase on the liquidus of a primitive magma.

In simple experimental magmatic systems, $\mathrm{Ru}, \mathrm{Os}$ and Ir tend to be concentrated into alloys and, to a lesser extent, sulfides, i.e., laurite at a relatively low fugacity of sulfur, $f\left(\mathrm{~S}_{2}\right)$, and high temperatures $\left(1200-1300^{\circ} \mathrm{C}\right)$ (Brenan \& Andrews 2001). Where the magma in such a system has a suitable $f\left(\mathrm{~S}_{2}\right)$, the PGE sulfides will have the following order of precipitation: $\mathrm{RuS}_{2}, \mathrm{OsS}_{2}$ and $\mathrm{IrS}_{2}$ (Westland 1981). According to the recent experiments of Brenan \& Andrews (2001), laurite shows a composition of nearly pure $\mathrm{RuS}_{2}$ with low concentrations of Os and $\mathrm{Ir}$ at high temperatures and low $f\left(\mathrm{~S}_{2}\right)$. The formation of Os-rich laurite and erlichmanite $\left(\mathrm{OsS}_{2}\right)$ requires a higher $f\left(\mathrm{~S}_{2}\right)$ than that for Ru-rich laurite. Consequently, the Os-for-Ru substitution in laurite is promoted by an increase of $f\left(\mathrm{~S}_{2}\right)$ (Stockman \& Hlava 1984, Woods 1987,

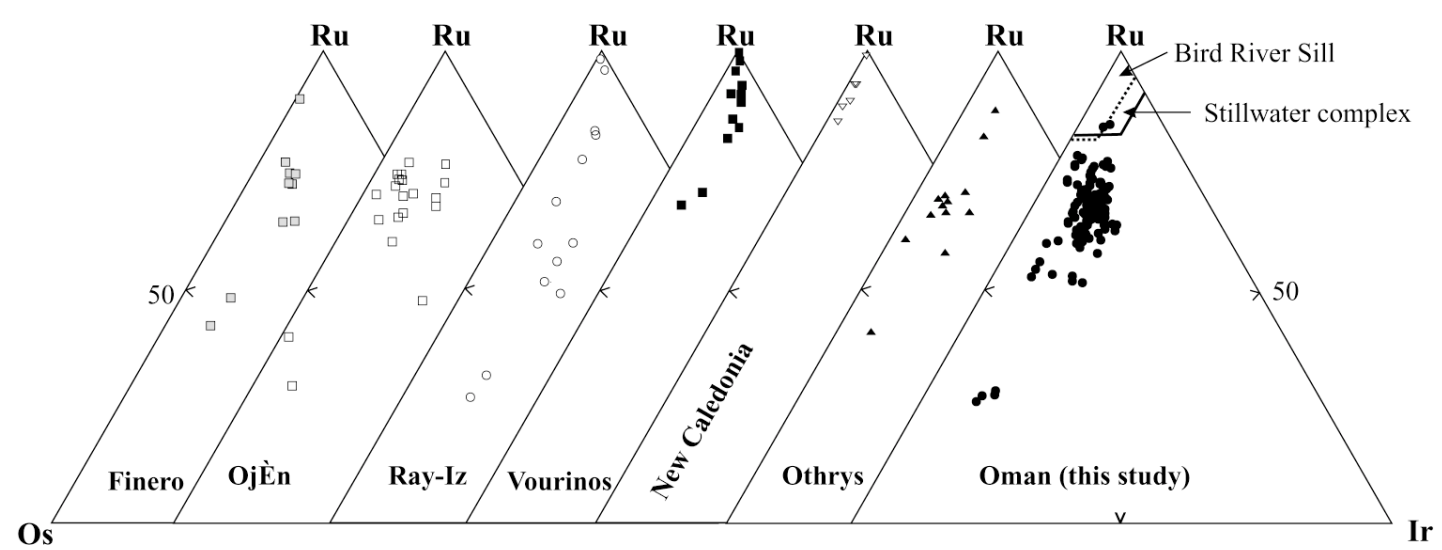

FIG. 10. Laurite compositions from ophiolites, peridotite complexes and layered intrusions plotted in the diagram Ru-Os-Ir (atomic proportions). Data sources: 1. Peridotite complexes: Finero, Italy (Ferrario \& Garuti 1990); Ojén, Spain (Garuti et al. 1995). 2. Ophiolites: Vourinos (Augé 1988); New Caledonia (Augé \& Maurizot 1995); Othrys, Greece (Garuti et al. 1999a), and Rai-Iz, Polar Urals, Russia (Garuti et al. 1999b). 3. Layered intrusions: Stillwater complex, Montana (Talkington \& Lipin 1986), and Bird River Sill complex, Manitoba, Canada (Ohnenstetter et al. 1986). 
Garuti et al. 1999a, Brenan \& Andrews 2001). The Rurich Os-Ir alloy also tends to be stable under relatively low $f\left(\mathbf{S}_{2}\right)$. Under conditions of high $f\left(\mathbf{S}_{2}\right), \mathrm{Ru}$ in the magma is consumed for the laurite formation, and thus the alloy grains trapped by chromian spinel, if any, will be Ru-poor (Nakagawa \& Franco 1997).

Hence, the common abundance of Os-rich laurite and the rarity of erlichmanite and (Ru-poor) Os-Ir alloy, especially in the PGE-rich chromitite of the Oman ophiolite, suggest that the initial $f\left(\mathrm{~S}_{2}\right)$ of the magma was high enough to form Os-rich laurite. We believe, therefore, that the magmas involved in the formation of chromitite in the Oman ophiolite were sulfide-undersaturated, and that the Os-rich laurite crystallized at a higher $f\left(\mathbf{S}_{2}\right)$ than in other complexes, where the laurite composition is more Ru-rich.

The mechanism of laurite formation as inclusions in chromian spinel is best explained by the "metal-clusters hypothesis" proposed by Tredoux et al. (1995). After liberation of the PGE from the mantle source at a high degree of partial melting, they tend to occur as minute metallic clusters in the host melt. Such metallic clusters will move upward with the melt until they reach the favorable conditions for chromitite formation, at which point they will act as a nucleus for the earlyformed crystals of chromian spinel and silicates (Tredoux et al. 1995). The subsequent formation of PGE alloys or sulfides will be controlled by the available sulfur content of the magma before entrapment by the early-formed crystals of chromian spinel.

The Os content of laurite seems to be dependent on the temperature and $f\left(\mathrm{~S}_{2}\right)$ of the host melt. The laurite silicate melt partition coefficient for Os significantly increases with decreasing temperature (Brenan \& Andrews 2001), and, therefore, the late-formed laurite tends to be more Os-rich. The early crystallization of laurite will result in the partitioning of Os into the solid phase, i.e., laurite, over the coexisting silicate melt. With decreasing temperature, the $f\left(\mathbf{S}_{2}\right)$ will increase, allowing laurite crystals to accommodate more Os and Ir to produce the Os-rich laurite prior to its incorporation within chromian spinel. On the other hand, quick entrapment of laurite into chromian spinel owing to a high cooling rate of magma is necessary to form Ru-rich laurite, precluding exchange of Os and Ir in the melt with $\mathrm{Ru}$ in the laurite once crystallized. If the magma reaches the sulfide-saturated conditions, almost all the PGE in the melt will be precipitated as monosulfide solid-solution, precluding (or postdating) the presence of laurite or alloys in the magmatic system (Barnes \& Naldrett 1986, Naldrett et al. 1994, Li et al. 1992, 1998, Brenan \& Andrews 2001, Andrews \& Brenan 2002).

The rarity of BMS in the PGE-rich chromitite of the Oman ophiolite can be explained by the abnormally high PGE contents that consume the available sulfur in the melt in order to produce Os-rich laurite (Augé 1988). The enrichment of some PGM with some base metals like $\mathrm{Cu}$ and $\mathrm{Ni}$ reflects the presence of these metals in the parent magma without sufficient amount of sulfur to form sulfide(s). The presence of some PGE - basemetal alloys, such as $\mathrm{Cu}-\mathrm{Pt}-\mathrm{Fe}-\mathrm{Ir}-\mathrm{Rh}$ and $\mathrm{Ni}-\mathrm{Ru}-\mathrm{Os}-$ Ir alloys, within chromian spinel reflects a hightemperature condition and low availability of sulfur at the early stage of spinel growth. This situation is also comparable to the presence of sulfarsenides as primary phases in chromian spinel, ascribed to relatively high As activity (Torres-Ruiz et al. 1996). The activity of As declined rapidly after the formation of As-bearing minerals (i.e., Ir-Rh sulfarsenide) with falling temperature (Torres-Ruiz et al. 1996).

The abundance of unnamed ( $\mathrm{Ir}, \mathrm{Rh})(\mathrm{Ni}, \mathrm{Cu}, \mathrm{Fe})$ sulfide and Os-rich laurite in the PGE-poor chromitite may reflect the relatively high $f\left(\mathrm{~S}_{2}\right)$ of the mantle-derived melt beneath the mid-ocean ridge. The relatively low degree of partial melting involved in the formation of PGE-poor chromitite in the Oman ophiolite is supported by the very gentle negative slope of its PGE distribution patterns from Ru to Pd (Ahmed \& Arai 2002). The BMS inclusions in some MTZ and PGE-poor chromitites may support a higher activity of sulfur and lowtemperature conditions (Ferrario \& Garuti 1990). The very few PGM grains, mainly laurite, in the MTZ chromitite reflect the depletion in PGE of its parental evolved magma. The low Os:Ru ratio, 0.35 on average, of the MTZ chromitites of the Oman ophiolite denotes the fractionated nature of the parent magmas in terms of PGE.

\section{Origin of secondary PGM assemblages}

The PGE oxide from the Oman ophiolite was possibly formed at a very low temperature, where chromian spinel can remain chemically intact. At higher temperatures, i.e., higher degrees of serpentinization, chromian spinel in chromitite is not stable, being converted to $\mathrm{Fe}$ rich phases, ferrian chromite or Cr-bearing magnetite (e.g., Ahmed et al. 2001). This inference is supported by the absence of chlorite and the presence of serpentine-group minerals in the network of fractures. In addition, the formation of a PGE oxide likely proceeded at an early stage of serpentinization because peridotites surrounding the chromitite pods are relatively fresh. This situation is confirmed by the relatively low contents of $\mathrm{Fe}$ and $\mathrm{Ni}$ in the oxide (Fig. 7 in Ahmed et al. 2002): Fe and Ni are supplied from olivine on serpentinization. A Ni-Fe alloy is quite commonly associated with PGM in highly altered chromitites (e.g., Garuti \& Zaccarini 1997, Arai et al. 1999). Stockman \& Hlava (1984) concluded that Ru-rich alloys were formed by desulfurization from primary laurite with significant addition of $\mathrm{Fe}-\mathrm{Ni}$ during serpentinization. In the Nurali complex of the southern Urals, the Fe-rich $\mathrm{Ru}-$ Os-Ir oxide grains are solely associated with altered chromian spinel (Garuti et al. 1997). 
The PGE (Ru-Os-Ir) oxide grains from Oman were probably transformed from primary laurite by desulfurization and oxidation accompanied by volume reduction. Their polygonal shape and mode of occurrence as inclusions within chromian spinel are exactly the same as laurite (Figs. 6A-D). The Ru-Os-Ir proportions were almost unchanged during the desulfurization-oxidation process (Fig. 9). The preservation of Ru-Os-Ir proportions upon transformation from laurite to PGE oxides was also reported from the Vourinos ophiolite (Garuti \& Zaccarini 1997). Primary laurite as a precursor for PGE oxides is also suggested by the occurrences from the Nurali Complex: primary magmatic laurite is included only in fresh chromian spinel, whereas the oxides are found in ferrian chromite (Garuti et al. 1997). Owing to the brittle failure of chromian spinel grains, radial cracks developed throughout the spinel grains, and extended through some of the enclosed PGM. As a result, some of the laurite grains were exposed to an oxygenated fluid phase, and were, therefore, converted to the $\mathrm{Ru}-\mathrm{Os}-\mathrm{Ir}$ oxide with a significant reduction in volume. The absence of chlorite-group minerals within the network of fractures in spinel and PGE oxide grains and the presence of serpentine-group minerals only suggest that chromian spinel is not involved in the alteration, at least at the stage of PGE oxide formation. It is the Eh rather than temperature that possibly controlled the formation of PGE oxide in Oman (Garuti et al. 1997). Westland (1981) suggested that PGE sulfides can be transformed to PGE alloys or PGE oxides depending on Eh-pH changes in the system PGE-S- $\mathrm{H}_{2} \mathrm{O}$. Bowles (1986) suggested that either laurite or Ru-rich alloys can be precipitated in a lateritic environment depending on Eh-pH conditions. According to Brookins (1987), laurite is converted to $\mathrm{RuO}_{2}$ via $\mathrm{Ru}$ metal with an increase of Eh at a given $\mathrm{pH}$ in the system $\mathrm{Ru}-\mathrm{O}-\mathrm{H}-\mathrm{S}$ at low-temperature, low-pressure conditions. We suggest, therefore, that Eh enhancement on invasion of aqueous fluid has converted primary Os-bearing laurite to $\mathrm{Ru}-$ Os-Ir oxide through an alloy stage.

The mode of occurrence of almost all BMS and BMA, as well as some of PGM, in the fractured chromian spinel and interstitial matrix of the PGE-poor and MTZ chromitites suggest that they are secondary in origin, formed during the serpentinization process.

\section{Conclusions}

1. Mineralization in the platinum-group elements is described for the first time from the northern Oman chromitites. PGE mineralization is found mainly in the PGE-rich chromitite deeper within the mantle section and, to a lesser extent, in the PGE-poor chromitite found at the same level, although the MTZ chromitites rarely have PGM grains.

2. Os-rich laurite is the most common PGM, but all the other PGE also appear in mineral phase(s) that are minor in amount. Subordinate Os-Ir alloy and erlich- manite also are found in the northern Oman chromitites. The unnamed ( $\mathrm{Ir} \mathrm{Rh})(\mathrm{Ni}, \mathrm{Cu}, \mathrm{Fe})$ sulfide is only common in the PGE-poor chromitite. PGE sulfarsenide and some other unidentified PGE alloys are observed as primary inclusions within chromian spinel. The variable mineral assemblages suggest crystallization under a wide range of $\mathrm{S}$ and As activities prior to or during the crystallization of chromian spinel.

3. The common abundance of Os-rich laurite and Ru-poor Os-Ir alloy suggests that the parent magma(s) involved in the formation of the northern Oman chromitite was sulfide-undersaturated. The Os-Ir alloy precipitated at the very early stage of crystallization, whereas the erlichmanite was precipitated at relatively high- $f\left(\mathrm{~S}_{2}\right)$ and low-temperature conditions.

4. A PGE oxide is found in the Oman ophiolite. Polygonal inclusions with radial cracks occur in unaltered grains of chromian spinel and are composed of $\mathrm{Ru}$, $\mathrm{Os}$, Ir and $\mathrm{O}$ with small amounts of $\mathrm{Fe}$. Its $\mathrm{Ru}-\mathrm{Os}-\mathrm{Ir}$ proportions are similar to that of primary Os-bearing laurite (Ru-Os-Ir sulfide), the most common PGM in the Oman chromitites.

5. The oxide formed by desulfurization and oxidation of the laurite, with appreciable reduction in volume at very low-temperature condition, at which chromian spinel remained chemically intact. An increase of Eh possibly promoted the transformation of laurite to PGE oxide via an alloy stage.

6. The occurrence of BMS and BMA in fractures in chromian spinel and in the matrix reflects their secondary origin; they formed progressively during the serpentinization process.

\section{ACKNOWLEDGEMENTS}

This study was financially supported by the Japan Society for the Promotion of Science (JSPS) through a post-doctorate fellowship to the first author. The authors express their appreciation to the geological staff in the Ministry of Commerce and Industry, Sultanate of Oman, for their help in facilitating the field work in the northern Oman Mountains. Collaboration with S. Miyashita, K. Kadoshima, and J. Uesugi are greatly appreciated. The authors are also grateful to S. Mondal, an anonymous reviewer, and Associate Editor E.M. Ripley, for their constructive comments. The comments of R.F. Martin are highly appreciated.

\section{REFERENCES}

Ahmed, A.H. \& AraI, S. (2002): Unexpectedly high-PGE chromitite from the deeper mantle section of the northern Oman ophiolite and its tectonic implications. Contrib. Mineral. Petrol. 143, 263-278.

\& AтtiA, A.K. (2001): Petrological characteristics of the Pan African podiform chromitites and associated peridotites of the Proterozoic ophiolite complexes, Egypt. Mineral. Deposita 36, 72-84. 
\& Kadoshima, K. (2002): Possible platinum-group element (PGE) oxides in the PGE-mineralized chromitite from the northern Oman ophiolite. J. Mineral. Petrol. Sci. 79, 190-198.

Andrews, D.R.A. \& Brenan, J.M. (2002): Phase-equilibrium constraints on the magmatic origin of laurite $+\mathrm{Ru}-\mathrm{Os}-\mathrm{Ir}$ alloy. Can. Mineral. 40, 1705-1716.

Arai, S., Prichard, H.M., Matsumoto, I. \& Fisher, P.C. (1999): Platinum-group minerals in podiform chromitite from the Kamuikotan Zone, Hokkaido, northern Japan. Resource Geology 49, 39-47.

Arculus, R.J. \& Delano, J.W. (1981): Siderophile element abundances in the upper mantle: evidence for a sulfide signature and equilibrium with the core. Geochim. Cosmochim. Acta 55, 1159-1172.

AugÉ, T. (1985): Platinum-group mineral inclusions in ophiolitic chromitite from the Vourinos complex, Greece. Can. Mineral. 23, 163-171.

(1986): Platinum-group-mineral inclusions in chromitites from the Oman ophiolite. Bull. Minéral. 109, 301-304.

(1988): Platinum-group minerals in the Tiebaghi and Vourinos ophiolitic complexes: genetic implications. Can. Mineral. 26, 177-192.

\& Legendre, O. (1994): Platinum-group element oxides from the Pirogues ophiolitic mineralization, New Caledonia: origin and significance. Econ. Geol. 89, 14541468.

\& Maurizot, P. (1995): Stratiform and alluvial platinum mineralization in the New Caledonia ophiolite complex. Can. Mineral. 33, 1023-1045.

BacutA, G.C., LiPIN, B.R., GibBS, A.K. \& KAY, R.W. (1988): Platinum-group elements abundance in chromite deposits of the Acoje ophiolite block, Zambales ophiolite complex, Philippines. In Geo-Platinum Symposium Volume (H.M. Prichard, P.J. Potts, J.F.W. Bowles \& S.J. Cribb, eds.). Elsevier, Amsterdam, The Netherlands (381-382).

BaI, W., Robinson, P.T., FAng, Q., YANG, J., YAN, B., Zhang, Z., Hu, X-F., Zhou, M.-F. \& Malpas, J. (2000): The PGE and base-metal alloys in the podiform chromitites of the Luobusa ophiolite, southern Tibet. Can. Mineral. 38, 585598.

Barnes, S.-J. \& NALdRetT, A.J. (1986): Variations in platinum-group element concentration in the Alexo mine komatiite, Abitibi greenstone belt, northern Ontario. Geol. Mag. 123, 515-524.

BowlEs, J.F.W. (1986): The development of platinum-group minerals in laterites. Econ. Geol. 81, 1278-1285.

Brenan, J.M. \& Andrews, D.R.A (2001): High-temperature stability of laurite and $\mathrm{Ru}-\mathrm{Os}-\mathrm{Ir}$ alloys and their role in PGE fractionation in mafic magmas. Can. Mineral. 39, 341-360.

BRookINS, D.G. (1987): Platinoid element Eh-pH diagrams $\left(25^{\circ} \mathrm{C}, 1 \mathrm{bar}\right)$ in the systems $\mathrm{M}-\mathrm{O}-\mathrm{H}-\mathrm{S}$ with geochemical applications. Chem. Geol. 64, 17-24.
Brown, M.A (1982): Chromite Deposits and Their Ultramafic Host Rocks in the Oman Ophiolite. Ph.D. thesis, Open Univ., Milton Keynes, U.K.

CABRI, L.J. (1981): Platinum-Group Elements: Mineralogy, Geology, Recovery. Can. Inst. Mining Metall., Spec. Vol. 23.

CorrivauX, L. \& Laflamme, J.H.G. (1990): Minéralogie des éléments du groupe du platine dans les chromitites de l'ophiolite de Thetford Mines, Québec. Can. Mineral. 28, 579-595.

Crocket, J.H. (1979): Platinum-group elements in mafic and ultramafic rocks, a survey. Can. Mineral. 17, 391-402.

Economou, M.I. (1986): Platinum-group elements (PGE) in chromite and sulfide ores within the ultramafic zone of some Greek ophiolite complexes. In Metallogeny of Basic and Ultrabasic Rocks (M.J. Gallagher, R.A. Ixer, C.R. Neary \& H.M. Prichard, eds.). The Institution of Mining and Metallurgy, London, U.K. (441-454).

Ferrario, A. \& GARUTI, G. (1990): Platinum-group mineral inclusions in chromitites of the Finero mafic-ultramafic complex (Ivrea-Zone, Italy). Mineral. Petrol. 41, 125-143.

Garuti, G., Gazzotti, M. \& ToRres-Ruiz, J. (1995): Iridium, rhodium and platinum sulfides in chromitites from the ultramafic massifs of Finero, Italy, and Ojén, Spain. Can. Mineral. 33, 509-520.

\& ZACCARINI, F. (1997): In situ alteration of platinum-group minerals at low temperature: evidence from serpentinized and weathered chromitite of the Vourinos complex, Greece. Can. Mineral. 35, 611-626.

Cabella, R. \& German, F. (1997): Occurrence of unknown $\mathrm{Ru}-\mathrm{Os}-\mathrm{Ir}-\mathrm{Fe}$ oxide in the chromitites of the Nurali ultramafic complex. Can. Mineral. 35, 1431-1440.

\& ECONOMOU-Eliopoulos, M. (1999a): Paragenesis and composition of laurite from chromitites of Othrys (Greece): implications for Os-Ru fractionation in ophiolitic upper mantle of the Balkan peninsula. Mineral. Deposita 34, 312-319.

, Moloshag, V. \& Alimov, V. (1999b): Platinum-group minerals as indicators of sulfur fugacity in ophiolitic upper mantle: an example from chromitites of the Ray-Iz ultramafic complex, Polar Urals, Russia. Can. Mineral. 37, 1099-1115.

Leblanc, M. (1991): Platinum-group elements and gold in ophiolitic complexes: distribution and fractionation from mantle to oceanic floor. In Ophiolite Genesis and Evolution of the Oceanic Lithosphere, Oman (T. Peters et al., eds.). Kluwer, Dordrecht, The Netherlands (231-260).

\& Ceuleneer, G. (1992): Chromite crystallization in a multicellular magma flow: evidence from a chromitite dikes in the Oman ophiolite. Lithos 27, 231-257.

Legendre, O. \& AugÉ, T. (1986): Mineralogy of platinumgroup mineral inclusions in chromitites from different ophiolitic complexes. In Metallogeny of Basic and Ultrabasic Rocks (M.J. Gallagher, R.A. Ixer, C.R. Neary \& H.M. Prichard, eds.). The Institution of Mining and Metallurgy, London, U.K. (361-372). 
Li, Chusi, Barnes, S.-J., Makovicky, E., Rose-Hansen, J. \& MAKovickY, M. (1998): Partitioning of nickel, copper, iridium, rhenium, platinum and palladium between monosulfide solid solution and sulfide liquid: effects of composition and temperature. Geochim. Cosmochim. Acta 60 1231-1238.

, Naldrett, A.J., Coats, C.J.A. \& Johannessen, P. (1992): Platinum, palladium, gold, and copper-rich stringers at the Strathcona mine, Sudbury: their enrichment by fractionation of a sulfide liquid. Econ. Geol. 87, 1584-1598.

Lippard, S.J., Shelton, A.W. \& Gass, I.G. (1986): The ophiolite od northern Oman. Geol. Soc., Mem. 11 Blackwell Scientific Publications, Oxford, U.K.

Melcher, F., Grum, W., Simon, G., Thalhammer, T.V. \& StuMPf, E.F. (1997): Petrogenesis of giant chromite deposits of Kempirsai, Kazakhstan: a study of solid and fluid inclusions in chromite. J. Petrol. 38, 1419-1458.

NAKAgawa, M. \& Franco, H.E.A. (1997): Placer Ru-Os-Ir alloys and sulfides: indicators of sulfur fugacity in an ophiolite? Can. Mineral. 35, 1441-1452.

NALDRETT, A.J. \& CABRI, L.J. (1976): Ultramafic and related mafic rocks: their classification and genesis with special reference to the concentration of nickel sulfides and platinum-group elements. Econ. Geol. 71, 1131-1158.

Pessaran, A., Asif, M. \& Li, Chusi (1994): Compositional variation in the Sudbury ores and prediction of the proximity of footwall copper-PGE orebodies. In The Sudbury-Noril'sk Symposium (P.C. Lightfoot \& A.J. Naldrett, eds.). Ontario Geol. Surv., Spec. Publ. 5, 133143.

Nicolas, A. \& Al AzRi, H. (1991): Chromite-rich and chromite-poor ophiolites: the Oman case. In Ophiolite Genesis and Evolution of the Oceanic Lithosphere, Oman ( $\mathrm{T}$. Peters et al., eds.). Kluwer, Dordrecht, The Netherlands (261-274).

Ohnenstetter, D., Watkinson, D.H., Jones, P.C. \& TALKINGTON, R. (1986): Cryptic compositional variation in laurite and enclosing chromite from the Bird River Sill, Manitoba. Econ. Geol. 81, 1159-1168.

Ohnenstetter, M., Karaj, N., Neziraj, A., Johan, Z. \& Cina, A. (1991): Le potentiel platinifère des ophiolites: minéralisations en éléments du groupe du platine (PGE) dans les massifs de Tropoja et Bulquiza, Albanie. C.R. Acad. Sci. Paris 13, Sér. II, 201-208.

Page, N.J., Cassard, D. \& HaffTy, J. (1982a): Palladium, platinum, rhodium, ruthenium, and iridium in chromitites from the Massif du Sud and Tiebaghi Massif, New Caledonia. Econ. Geol. 77, 1571-1577.

Pallister, J.S., Brown, M.A., SMewing, J.D. \& HAFFTY, J. (1982b): Palladium, platinum, rhodium, iridium, and ruthenium in chromite-rich rocks from the Samail ophiolite, Oman. Can. Mineral. 20, 537-548.

PRICHARD, H.M., LoRD, R.A. \& NEARY, C.R. (1996a): A model to explain the occurrence of platinum- and palladium-rich ophiolite complexes. J. Geol. Soc. London 153, 323-328.
, Puchelt, H., Eckhardt, J.-D. \& Fisher, P.C. (1996b): Platinum-group element concentrations in mafic and ultramafic lithologies drilling from Hess Deep. In Proc. Ocean Drilling Program (C. Mével, K.M. Gillis, J.F. Allan \& P.S. Meyer, eds.). Sci. Res. 147, 77-90.

Proenza, F., Gervilla, F., Melgarejo, J.C., Vera, O., Alfonso, P. \& FALlick, P. (2001): Genesis of sulfide-rich chromite ores by the interaction between chromitite and pegmatitic olivine-norite dikes in the Potosi mine (MoaBaracoa ophiolite massif, eastern Cuba). Mineral. Deposita 36, 658-669.

Stockman, H.W. \& Hlava, P.F. (1984): Platinum-group minerals in Alpine chromitites from southwestern Oregon. Econ. Geol. 79, 491-508.

TALKINGTON, R.W. \& LiPIN, B.R. (1986): Platinum-group minerals in chromite seams of the Stillwater complex, Montana. Econ. Geol. 81, 1179-1186.

TARKian, M., Economou-Eliopoulos, M. \& Eliopoulos, D.G. (1992): Platinum-group minerals and tetraauricupridein ophiolitic rocks of Skyros Island, Greece. Mineral. Petrol. 47, 55-66.

\& SAMBANIS, G. (1996): Platinum-group minerals in chromitites from the Pindos ophiolite complex, Greece. Neues Jahrb. Mineral., Monatsh., 145-160.

Naidenova, E. \& Zhelyaskova-Panayotova, M. (1991): Platinum-group minerals in chromitites from the Eastern Rhodope ultramafic complex, Bulgaria. Mineral. Petrol. 44, 73-87.

Thalhammer, M. \& Stumpfl, E.F. (1988): Platinum-group minerals from Hochgrössen ultramafic massif, Styria: first reported occurrence of PGM in Austria. Trans. Inst. Mining Metall. (Sect. B: Appl. Earth Sci.) 97, 77-82.

Torres-Ruiz, J., Garuti, G., Gazzotti, M., Gervilla, F. \& FenOll HaCH-Alí, P. (1996): Platinum-group minerals in chromitites from the Ojén lherzolite massif (Serranía de Ronda, Betic Cordillera, southern Spain). Mineral. Petrol. 56, 25-50.

Tredoux, M., Lindsay, N.M., Davies, G. \& McDonald, L. (1995): The fractionation of platinum-group elements in magmatic system, with the suggestion of a novel causal mechanism. S. Afr. J. Geol. 98, 157-167.

Westland, A.D. (1981): Inorganic chemistry of platinumgroup elements. In Platinum-Group Elements: Mineralogy, Geology, Recovery (L.J. Cabri, ed.). Can. Inst. Mining Metall., Spec. Vol. 23, 7-17.

Woods, S.A. (1987): Thermodynamic calculations of the volatility of the platinum group elements (PGE): the PGE content of fluids at magmatic temperatures. Geochim Cosmochim Acta 51, 3041-3050.

Received October 15, 2002, revised manuscript accepted April 25, 2003. 